\title{
A full greenhouse gases budget of Africa: synthesis, uncertainties, and vulnerabilities
}

\author{
R. Valentini ${ }^{1,2}$, A. Arneth ${ }^{3}$, A. Bombelli ${ }^{2}$, S. Castaldi ${ }^{2,4}$, R. Cazzolla Gatti ${ }^{1}$, F. Chevallier ${ }^{5}$, P. Ciais ${ }^{5}$, E. Grieco ${ }^{2}$, \\ J. Hartmann ${ }^{6}$, M. Henry ${ }^{7}$, R. A. Houghton ${ }^{8}$, M. Jung ${ }^{9}$, W. L. Kutsch ${ }^{10}$, Y. Malhi ${ }^{11}$, E. Mayorga ${ }^{12}$, L. Merbold ${ }^{13}$, \\ G. Murray-Tortarolo ${ }^{15}$, D. Papale ${ }^{1}$, P. Peylin ${ }^{5}$, B. Poulter ${ }^{5}$, P. A. Raymond ${ }^{14}$, M. Santini ${ }^{2}$, S. Sitch ${ }^{15}$, G. Vaglio \\ Laurin $^{2,16}$, G. R. van der Werf ${ }^{17}$, C. A. Williams ${ }^{18}$, and R. J. Scholes ${ }^{19}$
}

${ }^{1}$ Department for Innovation in Biological, Agro-food and Forest systems (DIBAF), University of Tuscia, via S. Camillo de Lellis, 01100 Viterbo, Italy

${ }^{2}$ Euro-Mediterranean Center on Climate Change (CMCC), Via Augusto Imperatore 16, 73100 Lecce, Italy

${ }^{3}$ Karlsruhe Institute of Technology, Institute of Meteorology and Climate Research, Atmospheric Environmental Research, Kreuzeckbahn Str. 19, 82467 Garmisch-Partenkirchen, Germany

${ }^{4}$ Dipartimento di Scienze Ambientali, Biologiche e Farmaceutiche (DISTABIF), Seconda Università di Napoli, via Vivaldi 43, 81100 Caserta, Italy

${ }^{5}$ LSCE, CEA-CNRS-UVSQ, L'Orme des Merisiers, Bat 701, 91191 Gif-sur-Yvette, France

${ }^{6}$ Institute for Biogeochemistry and Marine Chemistry, 20146, Hamburg, Germany

${ }^{7}$ FAO, Forestry Department, UN-REDD Programme, Viale delle terme di Caracalla 1, 00153 Rome, Italy

${ }^{8}$ Woods Hole Research Center, 149 Woods Hole Road, Falmouth, MA 02540, USA

${ }^{9}$ Biogeochemical Model Data Integration Group, Max Planck Institute for Biogeochemistry, Hans-Knöll Str. 10, 07745 Jena, Germany

${ }^{10}$ Thuenen Institute for Climate-smart Agriculture, Bundesallee 50, 38116 Braunschweig, Germany

${ }^{11}$ Environmental Change Institute, School of Geography and the Environment, University of Oxford, South Parks Road, Oxford, OX1 3QY, UK

${ }^{12}$ Applied Physics Laboratory, University of Washington, Seattle, WA 98105-6698, USA

${ }^{13}$ Department of Environmental Systems Science, Institute of Agricultural Sciences IAS, ETH Zurich, 8092 Zurich, Switzerland

${ }^{14}$ Yale School of Forestry and Environmental Studies, 195 Prospect St, New Haven, CT 06511, USA

${ }^{15}$ University of Exeter, Rennes Drive, Exeter EX4 4RJ, UK

${ }^{16}$ Department of Civil Engineering and Computer Science Engineering, University of Tor Vergata, Rome, Italy

${ }^{17}$ Faculty of Earth and Life Sciences, VU University Amsterdam, De Boelelaan 1085, 1081HV Amsterdam, the Netherlands

${ }^{18}$ Graduate School of Geography, Clark University, Worcester, MA 01610, USA

${ }^{19}$ Council for Scientific and Industrial Research, P.O. Box 395, Pretoria 0001 South Africa

Correspondence to: R. Valentini (rik@unitus.it)

Received: 23 January 2013 - Published in Biogeosciences Discuss.: 17 May 2013

Revised: 22 November 2013 - Accepted: 5 December 2013 - Published: 28 January 2014

\begin{abstract}
This paper, developed under the framework of the RECCAP initiative, aims at providing improved estimates of the carbon and GHG $\left(\mathrm{CO}_{2}, \mathrm{CH}_{4}\right.$ and $\left.\mathrm{N}_{2} \mathrm{O}\right)$ balance of continental Africa. The various components and processes of the African carbon and GHG budget are considered, existing data reviewed, and new data from different methodolo-
\end{abstract}

gies (inventories, ecosystem flux measurements, models, and atmospheric inversions) presented. Uncertainties are quantified and current gaps and weaknesses in knowledge and monitoring systems described in order to guide future requirements. The majority of results agree that Africa is a small sink of carbon on an annual scale, with an average value of 
$-0.61 \pm 0.58 \mathrm{Pg} \mathrm{C} \mathrm{yr}^{-1}$. Nevertheless, the emissions of $\mathrm{CH}_{4}$ and $\mathrm{N}_{2} \mathrm{O}$ may turn Africa into a net source of radiative forcing in $\mathrm{CO}_{2}$ equivalent terms. At sub-regional level, there is significant spatial variability in both sources and sinks, due to the diversity of biomes represented and differences in the degree of anthropic impacts. Southern Africa is the main source region; while central Africa, with its evergreen tropical forests, is the main sink. Emissions from land-use change in Africa are significant (around $0.32 \pm 0.05 \mathrm{Pg} \mathrm{C} \mathrm{yr}^{-1}$ ), even higher than the fossil fuel emissions: this is a unique feature among all the continents. There could be significant carbon losses from forest land even without deforestation, resulting from the impact of selective logging. Fires play a significant role in the African carbon cycle, with $1.03 \pm 0.22 \mathrm{Pg} \mathrm{C} \mathrm{yr}^{-1}$ of carbon emissions, and $90 \%$ originating in savannas and dry woodlands. A large portion of the wild fire emissions are compensated by $\mathrm{CO}_{2}$ uptake during the growing season, but an uncertain fraction of the emission from wood harvested for domestic use is not. Most of these fluxes have large interannual variability, on the order of $\pm 0.5 \mathrm{PgC} \mathrm{yr}^{-1}$ in standard deviation, accounting for around $25 \%$ of the year-toyear variation in the global carbon budget.

Despite the high uncertainty, the estimates provided in this paper show the important role that Africa plays in the global carbon cycle, both in terms of absolute contribution, and as a key source of interannual variability.

\section{Introduction}

Africa has the highest annual population growth rate in the world, at $2.3 \%$ in 2008 (UN, 2010). The population of Africa exceeded one billion inhabitants in 2009 (UN, 2011). At the same time, Africa has the lowest GDP of any continent and its economies rely mostly on natural resources, especially small-scale agriculture. In fact, $64 \%$ of people in subSaharan Africa (SSA) are employed in the rural sector and an estimated $90 \%$ of the continent's population depends on rain-fed crop production and pastoralism to meet its basic food supplies (IFAD, 2001; Patt and Winkler, 2007; UNSTAT, 2010). Population growth scenarios coupled with factors like increasing energy demand, intensive exploitation of natural resources for food and wood products, and associated land-use emissions make the African regional carbon budget and the processes driving GHG emission and uptake a particularly urgent topic for investigation.

Independent estimates of the African contribution to the global carbon cycle have recently been availed (Williams et al., 2007; Bombelli et al., 2009; Ciais et al., 2011). These studies combined various sources of data and various methodologies, from bottom-up ecosystem inventories to land fluxes, biogeochemical models, and atmospheric inversions. The results indicate a net biospheric sink of carbon. Nevertheless, there is still quite a significant range across the different estimates, from a near zero value to a net sink of 1.0 $\mathrm{Pg} \mathrm{C} \mathrm{yr}^{-1}$, with high uncertainties associated ${ }^{1}$.

The results presented in this paper are based on the most recent and comprehensive data sets, derived both from observational and modeling efforts; developed and/or made available under the framework of the Regional Carbon Cycle Assessment and Processes (RECCAP, http://www. globalcarbonproject.org/reccap) initiative of the Global Carbon Project (GCP) (Canadell et al., 2011). This provided an improved estimate of the carbon balance of continental Africa, along with balances for non- $\mathrm{CO}_{2}$ greenhouse gases through the integration of data from different sources and methodologies with related quantification of the uncertainties. In particular, a comprehensive review of available information together with newly produced data, from in situ, space-based and data assimilation systems, was conducted. Current gaps and weaknesses in knowledge and in the monitoring systems are also considered in order to provide indications on the future requirements. In particular, this paper will try (1) to disentangle various components and processes of the carbon budget and the potentials of today's methodologies to address them and (2) to extend the scope of previous studies by including a more comprehensive analysis of other greenhouse gases, specifically methane $\left(\mathrm{CH}_{4}\right)$ and nitrous oxide $\left(\mathrm{N}_{2} \mathrm{O}\right)$.

\section{Africa's GHG emissions and removals as reported to UNFCCC}

We have estimated the greenhouse gases (GHG) emissions on the basis of the national communication to the United Nations Framework Convention on Climate Change (UNFCCC) updated in December $2011^{2}$. The results reveal a profile of emissions from the African continent that is remarkably different to that of other regions of the world. Firstly, the contribution of fossil fuel emissions is low (less than $4 \%$ of total global $\mathrm{CO}_{2}$ emissions; Canadell et al., 2009a) but increasing rapidly. In terms of per capita emissions from

\footnotetext{
1 "C" indicates carbon from $\mathrm{CO}_{2}$ only; when $\mathrm{CH}_{4}$ and/or other non $\mathrm{CO}_{2} \mathrm{GHG}$ are included $\mathrm{CO}_{2}$-eq is used.

${ }^{2}$ Data were processed from the latest (updated to December 2011) African countries national communication to the UNFCCC (http://unfccc.int/national_reports/non-annex_i_natcom/ items/2979.php). Emission sources analysis has been developed considering the following sectors: anthropogenic emissions (regrouping emissions from the energy, industry and waste sectors); agriculture emissions; land-use change and forestry (LUCF) emissions; and removals (mainly by forests). The emissions rates include, when available, $\mathrm{CO}_{2}, \mathrm{CH}_{4}$ and $\mathrm{N}_{2} \mathrm{O}$; all the values were converted to $\mathrm{CO}_{2}$ equivalent $\left(\mathrm{CO}_{2}\right.$-eq) based on Global Warming Potential reported in IPCC (2007). The countries Libya, Mayotte, Reunion, Seychelles, Somalia, Zambia, Guinea Bissau, Liberia, Central African Republic and Equatorial Guinea were not considered in this analysis due to the lack or the inconsistency of the data reported in their National Communication.
} 
fossil fuel-based energy consumption, southern Africa, led by South Africa, has the highest per capita emission rate, at $8.5 \mathrm{MgCO}_{2}$-eq person ${ }^{-1} \mathrm{yr}^{-1}$ (i.e. 4 to 20 times the per capita emissions of other African regions).

The inventory data suggests that fossil fuel-based emissions from Africa are almost equal to the emissions from land-use change and forestry (LUCF), the latter including deforestation. Agriculture also plays an important role, amounting to $26 \%$ of total emissions (including $\mathrm{N}_{2} \mathrm{O}$ and $\mathrm{CH}_{4}$ ). It is important to underscore that LUCF emissions are more than one third (35\%) of total emissions in Africa, a share significantly higher than the $9 \%$ at the global level (GCP, 2011). These emissions are partially counterbalanced by removals from the atmosphere of about $2.24 \mathrm{PgCO}_{2}$-eq, mainly due to the forest sector of tropical Africa, resulting in a net source of $0.95 \mathrm{Pg} \mathrm{CO}_{2}$-eq. Comparing these data for the year 2011 with the study of Bombelli et al. (2009), there is clear evidence of an increasing trend in both fossil fuel and agricultural emissions. LUCF sector shows a decrease of about $0.38 \mathrm{Pg} \mathrm{CO}_{2}-$ eq compared with the 1994 reference year. This, combined with the simultaneous reduction in removals caused by a decreasing sink, results in increased emissions from 0.36 to $0.95 \mathrm{Pg} \mathrm{CO}_{2}$-eq (Table 1) compared to the 1994 reference year.

A sub-regional analysis (regrouping African countries into the five geographical sub-regions defined by the United Nations Statistics Division: western Africa, eastern Africa, northern Africa, central Africa, and southern Africa) shows that central Africa plays a key role as carbon sink, but at the same time, contributes the greatest emissions from the LUCF sector. This could be a sign of an increasing threat to local forest resources. Southern Africa (mainly due to South Africa), followed by North Africa, contribute more than other regions to the African fossil fuel emissions - with southern and North Africa being responsible for almost the total emissions. In the western and eastern Africa, agricultural and LUCF emissions dominate.

Therefore, according to national reports to the UNFCCC; and considering $\mathrm{CO}_{2}$ equivalents, Africa is a net source of $0.95 \mathrm{Pg} \mathrm{CO}_{2}$-eq per year, when focusing only on the carbon contribution of LUCF; and with the removals by forests, the net carbon budget of the African continent is a sink of $-0.31 \mathrm{PgC}^{-1}$, which is a small carbon sink on a whole continent on a year basis. However it must be noted that this estimate is the result of the difference between two large and uncertain numbers.

\section{The African carbon budget and its components}

Despite the availability of carbon budget estimates overall, there are many individual processes that are relevant for understanding the global carbon cycle. Indeed, $17 \%$ of global carbon emissions from land-use changes, more than a half of the global gross fire emissions, and about half of the in- terannual variability of the global carbon balance have been attributed to Africa (Williams et al., 2008; Canadell et al., 2009b; van der Werf et al., 2010). About $1 / 3$ of the tropical biomass carbon sink ( $16 \%$ of the total terrestrial carbon sink) over the period 2000 to 2005 is thought to result from the African tropical forests (Lewis et al., 2009; Malhi, 2010). However, these estimates carry large uncertainties, particularly regarding the role of Africa as carbon source or sink; the role of forest degradation and deforestation; and the interannual variability of the carbon fluxes. A complete and accurate greenhouse gas account for Africa (based on independent observed and modelled data instead of the self-estimations made by countries) is not yet available. In the subsequent sections we disentangle various processes and their contribution to the African GHG budget.

\subsection{Africa land cover: estimates and differences between various studies}

Estimation of land cover area and its change is critical for deriving bottom-up estimates from models, inventories and field data. This is particularly true when the land cover area is used to scale biomass estimates or fluxes of greenhouse gases from the local to the continental level. For this reason, we hereby try to quantify this source of uncertainty by comparing different land cover maps for Africa.

Several attempts have been made during the past few years to standardize land cover maps globally using a common reference classification system known as the FAO/UNEP Land Cover Classification System - LCCS ${ }^{3}$. Despite the common classification approach it remains difficult to compare different land cover products. We considered three widely used global land cover products (GCL2000, ${ }^{4}$ and GlobCover 2006 and $2009,{ }^{5}$ and tried to regroup the large number of classes into a smaller number: croplands, forests, shrublands/grasslands (including savannas), flooded vegetation, bare soil, water bodies, and others. The accuracy level ranges from $67.1 \%$ to $70.7 \%$, depending on the different land cover products; details on the methodology to assess the accuracy are given in the land cover Products Description and Validation Reports ${ }^{6}$. However, there are still remarkable differences in the areas reported, particularly for forests (Table 2). Forested area is reported for Africa to be between 638.2 and $836.8 \mathrm{Mha}$ - the range of variation is about $27 \%$ of the median value. According to FAO (FRA, 2010), deforestation in

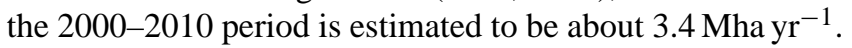
Thus, deforestation cannot by itself explain such big differences. As a consequence of the unexplained differences in

\footnotetext{
${ }^{3}$ http://www.glcn.org/ont_2_en.jsp)

${ }^{4}$ http://bioval.jrc.ec.europa.eu/products/glc2000/glc2000.php

${ }^{5} \mathrm{http}: / /$ due.esrin.esa.int/globcover

${ }^{6}$ http://dup.esrin.esa.int/files/p68/GLOBCOVER_Products_ Description_Validation_Report_I2.1.pdf, and http://due.esrin.esa. int/globcover/LandCover2009/GLOBCOVER2009_Validation_ Report_2.2.pdf
} 
Table 1. GHGs emission sources for five different African Regions.

\begin{tabular}{lccccccc}
\hline & \multicolumn{5}{c}{ Emission sources $\left(\mathrm{PgCO}_{2}\right.$-eq) } \\
\cline { 2 - 7 } Regions $^{1}$ & $\begin{array}{c}\text { Anthropogenic } \\
\text { fossil fuel } \\
\text { emissions }\end{array}$ & $\begin{array}{c}\text { Per capita }^{2} \\
\text { emissions } \\
\left(\mathrm{MgCO}_{2} \text {-eq }\right)\end{array}$ & Agriculture & LUCF & $\begin{array}{c}\text { Total } \\
\text { emissions }\end{array}$ & Removals & $\begin{array}{c}\text { Net } \\
\text { emissions }\end{array}$ \\
\hline North Africa & 0.344 & 2.1 & 0.120 & 0.051 & 0.514 & 0.038 & 0.476 \\
Eastern Africa & 0.157 & 0.8 & 0.279 & 0.209 & 0.645 & 0.426 & 0.219 \\
Western Africa & 0.289 & 1.3 & 0.307 & 0.386 & 0.981 & 0.513 & 0.469 \\
Central Africa & 0.029 & 0.4 & 0.067 & 0.459 & 0.555 & 1.181 & -0.626 \\
Southern Africa & 0.432 & 8.5 & 0.055 & 0.011 & 0.497 & 0.081 & 0.417 \\
\hline Total & 1.250 & & 0.828 & 1.115 & 3.193 & 2.238 & 0.954 \\
\hline Total by Bombelli et al. & 0.938 & & 0.465 & 1.495 & 2.860 & 2.505 & 0.359 \\
& & & & & & & \\
\hline
\end{tabular}

\footnotetext{
${ }^{1}$ According to the United Nations geographical sub-regions for Africa, from the United Nations Statistics Division: http://unstats.un.org/unsd/methods/m49/m49regin.htm\#africa. ${ }^{2}$ Per capita values are estimated on the base of UN World population prospect, the 2010 revision (2011).
}

Table 2. Different estimates of land cover in Africa across various products derived by space observation (GlobCover) and inventories (FAO).

\begin{tabular}{|c|c|c|c|c|c|}
\hline & $\begin{array}{r}\text { GlobCover2009 } \\
\text { (Mha) }\end{array}$ & $\begin{array}{r}\text { GlobCover2006 } \\
(\mathrm{Mha})\end{array}$ & $\begin{array}{r}\text { GLC2000 } \\
\text { (Mha) }\end{array}$ & $\begin{array}{r}\text { FAO FRA } \\
\text { (Mha) }\end{array}$ & $\begin{array}{r}\text { Range } \\
(\% \text { of } \\
\text { median })\end{array}$ \\
\hline $\begin{array}{l}\text { Croplands } \\
\text { (including mosaics of } \\
\text { grasslands and forests) }\end{array}$ & 468.7 & 499.3 & 477.3 & & 6.4 \\
\hline $\begin{array}{l}\text { Forests } \\
\text { (including mosaics of } \\
\text { forests and woodlands) }\end{array}$ & 740.6 & 836.8 & 638.2 & 674.4 & 26.8 \\
\hline $\begin{array}{l}\text { Shrublands/grasslands } \\
\text { (including savannas } \\
\text { and sparse vegetation) }\end{array}$ & 638.9 & 769.0 & 880.9 & & 14.8 \\
\hline Flooded vegetation & 43.8 & 52.0 & 3.4 & & 110.7 \\
\hline Bare soil & 991.5 & 1061.1 & 1047.1 & & 6.6 \\
\hline Water bodies & 28.2 & 28.9 & 28.3 & & 2.4 \\
\hline Others & 3.0 & 3.4 & 5.9 & & 85.2 \\
\hline Total & 2914.7 & 3250.4 & 3081.0 & & 10.9 \\
\hline
\end{tabular}

the forest areas, these land cover products cannot be used for deriving deforestation rates by simple differencing. A possible source of inconsistency between the different land cover products is the fact that they were not produced in the same reference year. Other possible reasons include the fact that the differences of the definitions within a land cover class (e.g. forests can include open forest, closed forest, sparse forest, woodlands, savannas, etc.), the different land cover classes used by the different products, and the presence of mixed classes (i.e. mosaics of forests, savannas, croplands, etc.) without the proportions of the different components.

Such uncertainty in area estimation of land cover classes can create large biases in estimating net fluxes and/or biomass changes, particularly in forests. In the other cate- gories, the variation in estimated areas is more limited. For croplands the range is $6.4 \%$ of the median, and for shrublands/grasslands it is $14.8 \%$.

\subsection{Biomass estimation}

Considering that around 16 to $17 \%$ of the world tropical forested area occurs in Africa (FAO, 2006), it is surprising how few carbon stocks estimations at the continental level have been published. Brown and Gaston (1995) produced one of the first estimates using forest inventory data combined with land-use modeling. Others based their analysis on remote sensing data and field-derived ground truth (Baccini et al., 2008, 2012; Saatchi et al., 2011). Lewis et al. (2009) analysed a network of research plots across Africa 
to estimate long-term changes in carbon stocks. At local level, aboveground biomass has been assessed in a number of specific forest sites (i.e. Henry, 2010; Glenday, 2008; Maniatis et al., 2011; Mitchard et al., 2011; Alam et al., 2013). Biomass data for African forests remains insufficient for accurate estimation and comparison to other world regions (Ciais et al., 2011). The same is true for other important land cover classes in Africa, such as savannas, shrublands, crops and wetlands.

In order to identify and visualize the pattern of aboveground biomass distribution, we integrated the land cover map of the European Space Agency (ESA), GlobCover 2009 product (Globcover Land Cover v2.3, 2009), and the map of aboveground biomass developed by the Woods Hole Research Center (WHRC) (Baccini et al., 2008). Integration implied the resampling of data to higher available resolution and the calculation of biomass statistical values for each land cover class. Both the biomass and land cover map were based on remote sensed and field data collected in the period between 2000 and 2009 and are among the most recent public domain products. All GIS analyses were conducted with data in sinusoidal projection, which is the original projection adopted in the WHRC biomass map. The WHRC biomass map is a $1 \mathrm{~km}$ raster data set expressed as $\mathrm{Mg}$ of biomass per hectare, saturating at $356 \mathrm{Mg} \mathrm{ha}^{-1}$. The GlobCover 2009 map is a $300 \mathrm{~m}$ raster data set (which spatial resolution was degraded to $1 \mathrm{~km}$ to match the WHRC map), developed according to the LCCS. It classifies vegetation using a pure physiognomic-structural method and is thus well suited for above ground biomass analysis. Forests in LCCS are by definition composed of trees with height $>5 \mathrm{~m}$ and a crown cover $>10 \%$.

The different GlobCover 2009 land cover classes considered in this study are shown in Table 3, together with the associated biomass values, their statistics and extent. After excluding the cells with zero biomass (assumed to be nonvegetated areas). The land cover classes were further aggregated as follows:

- Croplands (including mosaics of grasslands and forests): classes 20 and 30 .

- Forests (including mosaics of forests and woodland): classes 40, 50, 60, 70, 90, 100.

- Shrublands and grasslands (including savannas): classes 110, 120, 130, 140, 150.

- Flooded vegetation: classes 160, 170, 180.

For these aggregations, basic biomass statistics (Table 4) and histograms (Fig. 1) were computed to evaluate distribution patterns.

The croplands aggregation is characterized by mediumlow biomass values, with areas having higher biomass occupying about $20 \%$ of the extent. The higher biomass cells are found in compact clusters inside a highly human-influenced
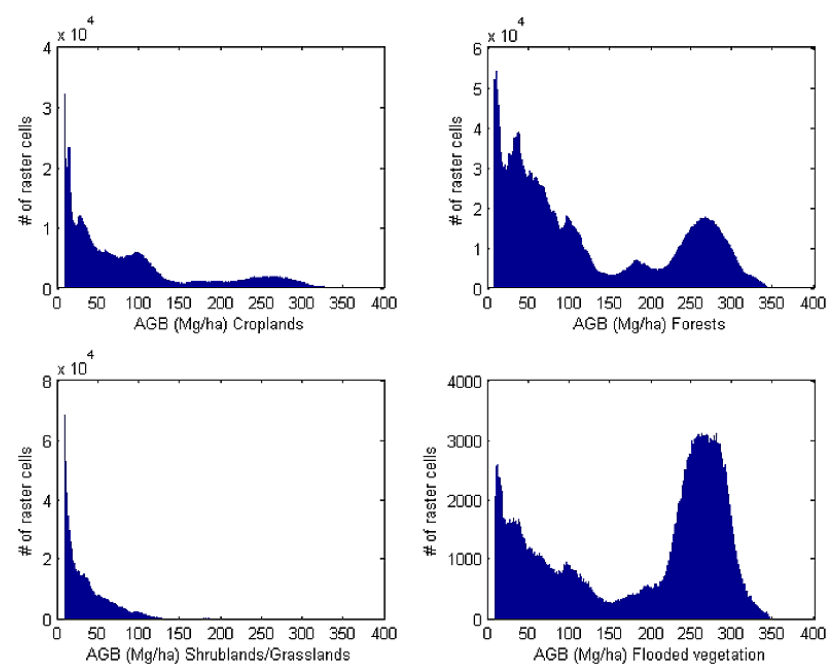

Fig. 1. Histograms of biomass for different land cover aggregated classes (see Table 4).

mosaic: they mostly belong to class 30 (Table 3 ), which also includes forest patches. These areas have a role in $\mathrm{C}$ stocks changes and can be prioritized for forest recovery activities. The forests aggregation is characterized by broad geographical distribution. The histogram (Fig. 1) has two peaks in a nearly bimodal distribution corresponding to two distinct areas of low and high biomass ranges. In this aggregation, cells belonging to class 40 (lowland tropical rainforest, Table 3) account for most of the areas of higher biomass. Their spatial distribution can be resumed in two large intact blocks in eastern and western central Africa; a smaller area in West Africa at the Liberia-Sierra Leone border; a smaller fraction with lower biomass around the above blocks and close to the coast, in highly anthropic areas. The shrublands/grasslands aggregation has the lowest biomass values and corresponds mainly to drier environments. The flooded vegetation aggregation includes areas of very high biomass, but its extent is relatively small. It occurs in clusters in the western Democratic Republic of Congo and Congo Republic. This block deserves to be prioritized for conservation activities.

We recognize that the used maps have some limitations. For instance, the GlobCover 2009 map has a lower accuracy in the flooded areas class (see the GlobCover 2009 validation report $)^{7}$, while the WHRC biomass map has been built with limited ground truth, coming only from three countries (Republic of Congo, Cameroon and Uganda) and collected at a distance of years from remote sensing data (Baccini et al., 2008). Furthermore, they do not cover non-tropical Africa. Nonetheless, despite these limitations, they are the freely accessible and most updated products available so far.

\footnotetext{
${ }^{7}$ http://due.esrin.esa.int/globcover/LandCover2009/ GLOBCOVER2009_Validation_Report_2.2.pdf
} 
Table 3. Biomass statistics and extent according to GlobCover 2009 land cover classes.

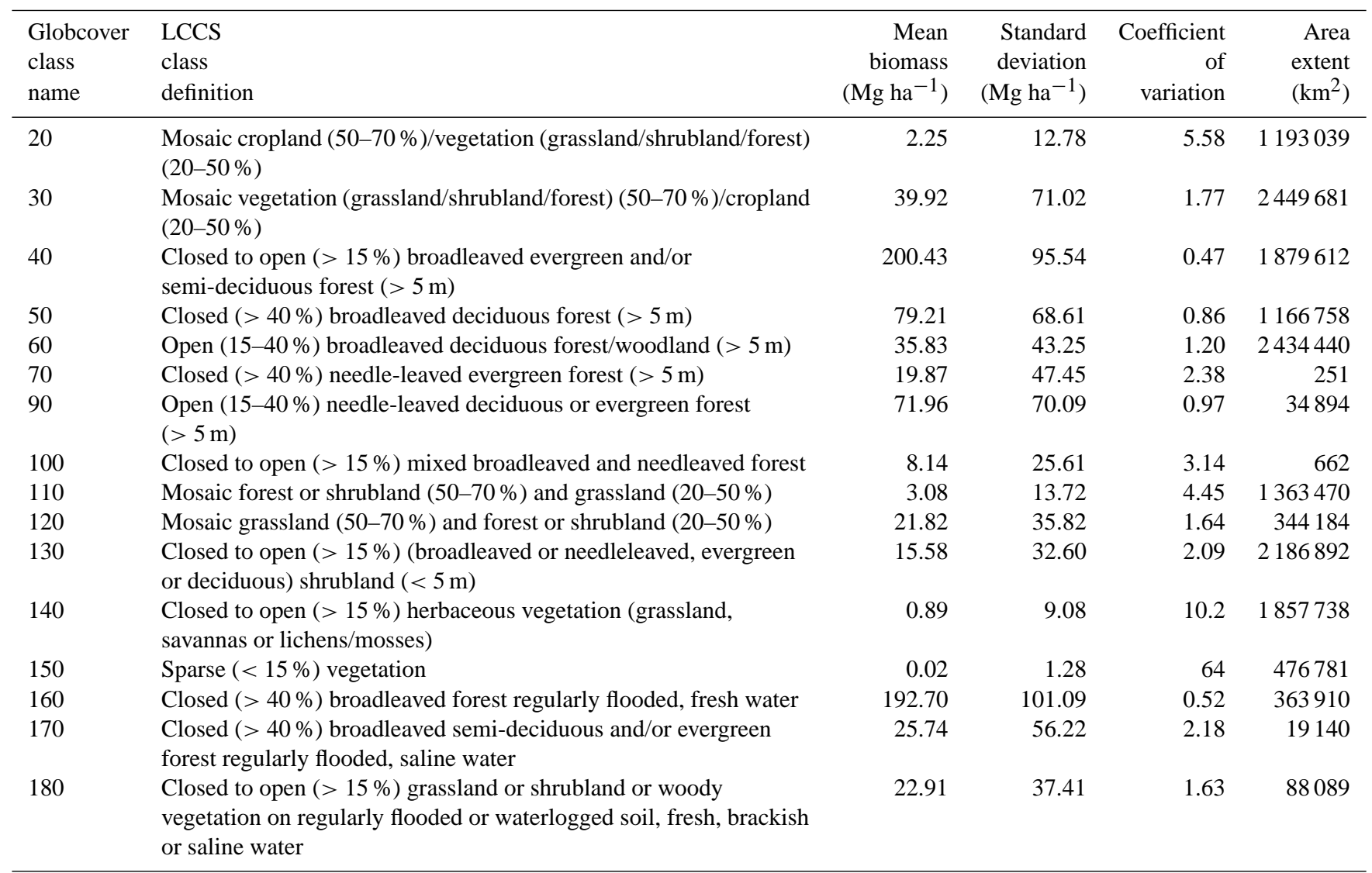

Table 4. Biomass values and extent according to aggregated GlobCover 2009 land cover classes.

\begin{tabular}{|c|c|c|c|c|c|c|c|}
\hline $\begin{array}{l}\text { Aggregated } \\
\text { classes }\end{array}$ & $\begin{array}{r}\text { Mean } \\
\text { biomass } \\
\left(\mathrm{Mgha}^{-1}\right)\end{array}$ & $\begin{array}{c}\text { Median } \\
\text { biomass } \\
\left(\mathrm{Mgha}^{-1}\right)\end{array}$ & $\begin{array}{c}\text { Standard } \\
\text { deviation } \\
\left(\mathrm{Mgha}^{-1}\right)\end{array}$ & $\begin{array}{r}5 \% \\
\text { percentile }\end{array}$ & $\begin{array}{r}95 \% \\
\text { percentile }\end{array}$ & Range & $\begin{array}{l}\text { Area } \\
\text { extent } \\
\left(\mathrm{km}^{2}\right)\end{array}$ \\
\hline Croplands & 87.95 & 60 & 81.68 & 11 & 270 & $9-344$ & 1142574 \\
\hline Forests & 123.4 & 84 & 99.17 & 13 & 292 & $9-356$ & 4529221 \\
\hline $\begin{array}{l}\text { Shrublands/grasslands } \\
\text { (including savannas) }\end{array}$ & 41.42 & 29 & 40.92 & 9 & 109 & $9-344$ & 1146337 \\
\hline Flooded vegetation & 183.79 & 233 & 102.15 & 17 & 300 & $9-356$ & 395203 \\
\hline
\end{tabular}

According to this analysis (Table 4), by multiplying the area extent of each class by its mean, it has been possible to estimate a total tropical African aboveground ground biomass of 77.9 Pg C, with different coefficients of variation according to the different land cover classes considered (Table 3). Considering that each data set is possibly affected by a 9 to $15 \%$ (min-max) representation error for each class, the cumulated error associated with the overall estimate of biomass in tropical Africa is of the order of 19 to $27 \%$ per class, which represents the minimum and maximum range of error that classes can have.

\subsection{Atmospheric inversions}

Inversions used in this study are Bayesian synthesis inversions where a prior set of surface fluxes is modified to match atmospheric $\mathrm{CO}_{2}$ observations, given a numerical model of atmospheric transport and a statistical description of the uncertainties of both the prior fluxes and the observations. Over Africa, inversions are poorly constrained by measurements from the atmospheric surface $\mathrm{CO}_{2}$ network. The main stations of the atmospheric surface network are located in South Africa (station CPT), Namibia (station NMB), Algeria (station ASK), Ivory Coast (station LTO) and in two islands downwind of the continent (stations IZO, in the Canary 
Islands, and ASC, in Ascencion Island). Furthermore, the importance of vertical mixing by convection during the wet season associated with the seasonal displacement of the ITCZ over Africa makes the simulation of $\mathrm{CO}_{2}$ transport particularly challenging, and reduces the influence of surface fluxes on atmospheric surface station $\mathrm{CO}_{2}$ variations in atmospheric transport model. As a consequence, inverted fluxes over Africa are subjected to large uncertainties and often reflect the prior fluxes used in the Bayesian inversion.

Early inversion estimates (from 5 inversions corresponding to the late 1990s period) compiled by Williams et al. (2007) suggested that Africa is close to $\mathrm{CO}_{2}$ neutral. This would imply that land-use $\mathrm{CO}_{2}$ emissions $\left(0.3 \mathrm{Pg} \mathrm{Cyr}^{-1}\right.$ in Friedlingstein et al., 2010) and fossil fuel $\mathrm{CO}_{2}$ emissions (0.26 $\mathrm{Pg} \mathrm{C} \mathrm{yr}^{-1}$ in Canadell et al., 2009a) are approximately in balance with a residual $\mathrm{CO}_{2}$ uptake by ecosystem processes not counted in the land-use $\mathrm{CO}_{2}$ emissions. The Net $\mathrm{CO}_{2}$ flux estimates over Africa given by inversions published in the late 1990s and early 2000s are $0.1 \mathrm{Pg} \mathrm{C} \mathrm{yr}^{-1}$ during 1985-1995 (Bousquet et al., 1999), $-0.4 \mathrm{Pg} \mathrm{C} \mathrm{yr}^{-1}$ and $0.25 \mathrm{Pg} \mathrm{C} \mathrm{yr}^{-1}$ from the average of 13 inversions of the TRANSCOM project during 1992-1996, in Gurney et al. (2002) (based on annual mean $\mathrm{CO}_{2}$ gradients) and in Gurney et al. (2003) (based on monthly mean $\mathrm{CO}_{2}$ gradients), respectively. Positive numbers denote net sources of $\mathrm{CO}_{2}$ to the atmosphere.

For this study, we specifically gathered the results from five more recent inversions with fluxes "solved" at the transport model spatial resolution (except for one, CTE2008 ${ }^{8}$ ). These inversions are described in Table 5. Note that, two of them correspond to a variant of the same system using different observation networks (JENA_s96 and JENA_s99). Over Africa, inversion estimates of the $\mathrm{CO}_{2}$ natural flux are $0.1 \mathrm{Pg} \mathrm{Cyr}^{-1}$ during 1996-2008 for JENA_s96; $-0.26 \mathrm{Pg} \mathrm{C} \mathrm{yr}^{-1}$ during 19992008 for JENA_s99; $0.21 \mathrm{Pg} \mathrm{C} \mathrm{yr}^{-1}$ during 2000-2007 for CTE2008; 0.32 $\mathrm{Pg} \mathrm{C} \mathrm{yr}^{-1}$ during 1996-2004 for LSCE_ana; and $-0.08 \mathrm{Pg} \mathrm{C} \mathrm{yr}^{-1}$ during 1988-2008 for LSCE_var. The inversion fluxes (including fossil fuel emissions) aggregated over Africa are showed in Fig. 2. The longest inversion (LSCE_var) over the period 1988-2008 gives a mean $\mathrm{CO}_{2}$ flux of $0.24 \pm 0.8 \mathrm{Pg} \mathrm{C} \mathrm{yr}^{-1}$ over northern Africa and a sink of $-0.15 \pm 0.9 \mathrm{Pg} \mathrm{C} \mathrm{yr}^{-1}$ over southern Africa (the uncertainty representing 1 sigma for a single year).

Despite the large uncertainty associated with the mean continental scale natural $\mathrm{CO}_{2}$ flux, the results from the five inversions displayed in Fig. 2 show coherent interannual variations of $\mathrm{CO}_{2}$ fluxes, though with different amplitudes. A strong source anomaly (positive land-atmosphere $\mathrm{CO}_{2}$ flux) during 1997-1998 associated with the positive-phase ENSO (El Niño-Southern Oscillation) condition is obtained for two systems, while during 2001-2002, most systems also pro-

\footnotetext{
${ }^{8}$ http://www.carboscope.eu/ (last access: 2 May 2011)
}

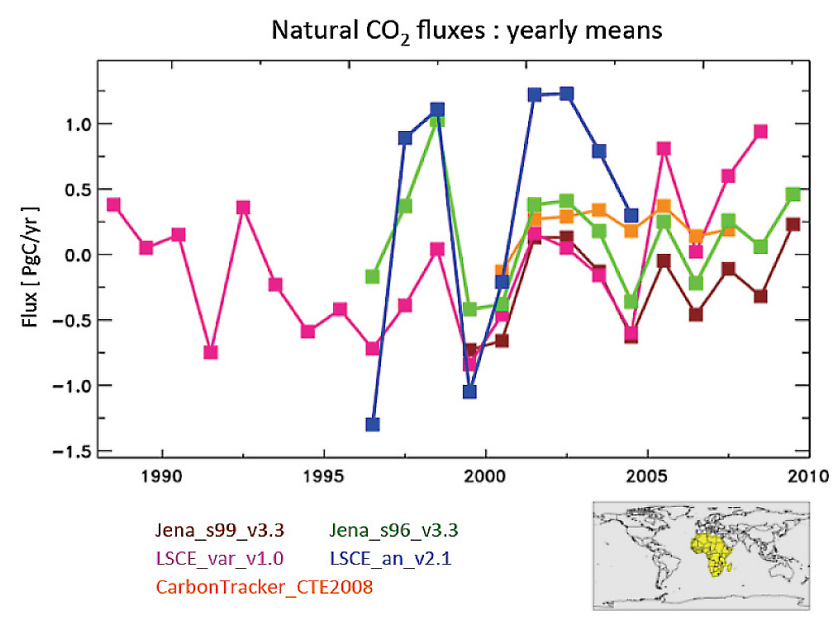

Fig. 2. Year to year variations in the net $\mathrm{CO}_{2}$ flux of Africa seen by five recent inversions. The $\mathrm{CO}_{2}$ flux includes land-use $\mathrm{CO}_{2}$ emissions and other ecosystem $\mathrm{CO}_{2}$ fluxes, and fossil $\mathrm{CO}_{2}$ emissions as well (http://www.carboscope.eu/).

vide a slightly positive flux without any significant phase of ENSO.

Figure 3a shows the geographic distribution of the mean land-atmosphere $\mathrm{CO}_{2}$ flux from these inversions, while Fig. $3 b$ shows the spread of the five inversions, defined from the estimator of the standard deviation. Note that the estimated spatial distribution is highly controlled by the a priori flux distribution, the location of imposed biomass burning (except for the two JENA systems), and the flux error correlation length used by the LSCE and JENA systems. Inversions appear to be consistent in placing a large uptake over central African forests $\left(-60 \mathrm{~g} \mathrm{C} \mathrm{m}^{-2} \mathrm{yr}^{-1}\right)$, although with an associated uncertainty of nearly similar magnitude. This feature is not surprising because all inversions allocate large prior errors to tropical forest fluxes, and since the region is not constrained by atmospheric measurements, the models tend to place large sink increments in this biome. On the other hand, the spread of the five inversions is much larger over savannas (Fig. 3b), in fact, larger than the mean flux (indicating positive or negative fluxes). This inconsistency may originate from different choices for the prior biomass burning fluxes or the prior natural fluxes. It is seen in Fig. 3a that some inversions use non-zero a priori fluxes, in particular for fire emissions in savannas.

In conclusion, although inversions are associated with significant uncertainties over the African continent, both earlier inversions and recent ones robustly converge toward a neutral to a slightly positive $\mathrm{CO}_{2}$ balance for Africa. However, these results have a standard deviation larger than $1 \mathrm{PgC}^{-1}$. New estimates of the African $\mathrm{CO}_{2}$ flux will soon be obtained from the observations from the greenhouse gases Observing Satellite (GOSAT, Kuze et al., 2010), launched in January 2009 by the JAXA (Japan Aerospace Exploration Agency). 
Table 5. Inversion systems used in this study and key attributes.

\begin{tabular}{llllllll}
\hline Acronym & Reference & \# of regions & Time period & Obs. ${ }^{\text {a }}$ & $\begin{array}{l}\text { \# of obs. } \\
\text { locations }\end{array}$ & $\begin{array}{l}\text { IAV }^{\mathrm{c}} \\
\text { wind }\end{array}$ & $\begin{array}{l}\text { IAV }^{\mathrm{d}} \\
\text { priors }\end{array}$ \\
\hline LSCE_ana(V2.1) & Piao et al. (2009) & Grid-cell $(96 \times 72)$ & $1996-2004$ & MM & 67 & Yes & No \\
LSCE_var (v1.0) & Chevallier et al. (2010) & Grid-cell $(96 \times 72)$ & $1988-2008$ & Raw & 128 & Yes & Yes \\
CTE2008 & Peters et al. (2009) & 156 & $2001-2008$ & Raw & 94 & Yes & Yes \\
JENA_s96(v3.3) & Rödenbeck (2005) & Grid-cell $(72 \times 48)$ & $1996-2009$ & Raw & 53 & Yes & No \\
JENA_s99(v3.3) & Rödenbeck (2005) & Grid-cell $(72 \times 48)$ & $1999-2009$ & Raw & 62 & Yes & No \\
\hline
\end{tabular}

a Observations used as monthly means (MM) or at sampling time (Raw).

b Number of measurement locations included in the inversion (some inversions use multiple records from a single location).

${ }^{\mathrm{c}}$ Inversion accounts for interannually varying transport (Yes) or not (No).

${ }^{\mathrm{d}}$ Inversion accounts for interannually varying prior fluxes (Yes) or not (No).

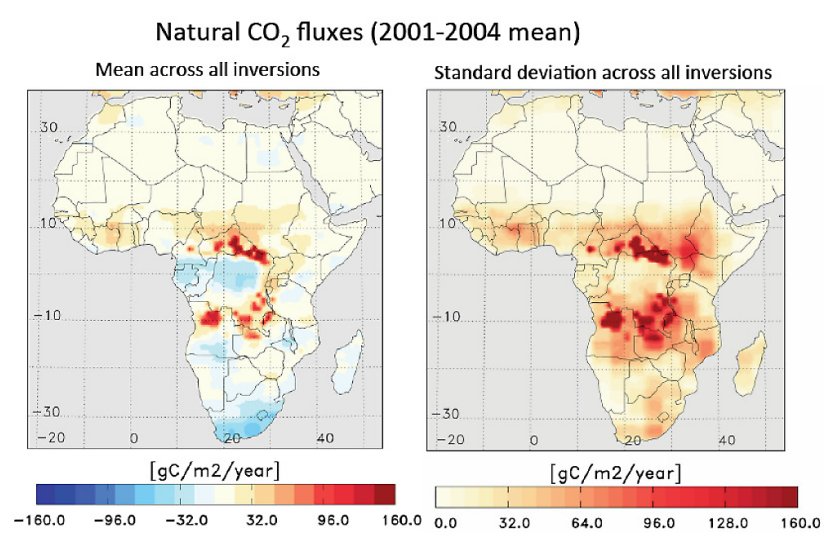

Fig. 3. (a) Distribution of mean $\mathrm{CO}_{2}$ fluxes averaged across the five recent inversions analysed. (b) shows the spread of the inversions (defined from the estimator of the standard deviation). Inversions have a different spatial resolution, and the fluxes have been interpolated on a common grid. Negative values are atmospheric $\mathrm{CO}_{2}$ sinks (http://www.carboscope.eu/).

The GOSAT satellite observations of column $\mathrm{CO}_{2}$ data cover the atmosphere over tropical continents much better than in situ stations, albeit with larger errors on individual soundings. The error on the $\mathrm{CO}_{2}$ balance of Africa is expected to be strongly reduced when GOSAT data have been assimilated (Chevallier et al., 2009), provided that these data will have no systematic bias. The errors on annual $\mathrm{CO}_{2}$ fluxes are expected to decrease from $\pm 1.3 \mathrm{Pg} \mathrm{Cyr}^{-1}$ (6\% error reduction from the assumed prior error) when using in situ data from the current atmospheric surface network, down to $\pm 0.4 \mathrm{Pg} \mathrm{C} \mathrm{yr}^{-1}$ ( $72 \%$ error reduction from the prior error) expected from the assimilation of GOSAT data, if those data have no bias.

\subsection{Terrestrial fluxes upscaled from in situ observations}

In recent years, there has been an expansion of the flux tower network in Africa (Bombelli et al., 2009). The total number of flux sites (see FLUXNET database) includes more than 15 sites with continuous carbon dioxide, water vapour, and energy fluxes, covering different plant functional types (from tropical forest, to transition forest and savannas) in different climatic regions. Some flux towers have been used in sporadic or seasonal campaign mode. The latest overview of the flux towers being active during CarboAfrica has been given in Merbold et al. (2009) and Sjöström et al. (2013).

The net annual carbon budget (NEE) of savanna sites ranges from a slight source of 0.25 to a sink of $-4.53 \mathrm{tC} \mathrm{ha}^{-1} \mathrm{yr}^{-1}$ (Bombelli et al., 2009), with a median value being a sink of $-0.14 \mathrm{tCha}^{-1} \mathrm{yr}^{-1}$. Recent data from East African tropical wetlands (Saunders et al., 2012) show a quite significant sink $\left(-10 \mathrm{tC} \mathrm{ha}^{-1} \mathrm{yr}^{-1}\right.$ and $-7 \mathrm{tCha}^{-1} \mathrm{yr}^{-1}$ ) for papyrus and cocoyam plantations, respectively.

There are still large gaps in our knowledge of NEE derived from in situ measurements for many ecosystems and climate regions of Africa. A first attempt to scale up the limited flux data was provided by Jung et al. (2011). Data-driven estimates of mean gross primary production (GPP), total ecosystem respiration (TER), and NEE for the period 19822008 based on the integration of FLUXNET, satellite, and meteorological observations using the model tree ensemble (MTE) approach (Jung et al., 2009) are $24.3 \pm 2.9 \mathrm{Pg} \mathrm{C} \mathrm{yr}^{-1}$, $19.0 \pm 1.4 \mathrm{Pg} \mathrm{C} \mathrm{yr}^{-1}$, and $-3.7 \pm 1.6 \mathrm{PgC} \mathrm{yr}^{-1}$, respectively (Jung et al., 2011). Uncertainties refer to one standard deviation of the spread of the 25 members of the model tree ensemble, and reflect the uncertainty in the structure of the model trees. Uncertainties related to FLUXNET data and global forcing data sets are not included in this measure. The NEE estimates are not consistent with the difference of TER and GPP because NEE was upscaled independently. The "La Thuile FLUXNET data set" was screened for the high quality data and the availability of required variables. ${ }^{9}$ Because only one African flux data were available for training at the time, uncertainties due to extrapolation to African ecosystem are likely to be substantial. Jung et al. (2011) inferred a systematic underestimation of 5 to $10 \%$ of their

\footnotetext{
${ }^{9}$ www.fluxdata.org
} 
global TER value, likely due to a biased sampling with enhanced representation of young and regrowing forests in the La Thuille database and an even larger bias when considering African ecosystems only. The uncertainties of the NEE value are very large, as inferred by cross-validation (Jung et al., 2011) because determinants of mean NEE, such as site history, management, and disturbances, could not be accounted for explicitly in the MTE approach. The apparent strong sink of $-3.7 \mathrm{PgC}^{-1}$ is most likely a large overestimation, given that this number does not capture disturbed ecosystems being sources of $\mathrm{CO}_{2}$. A second data-driven approach based on artificial neural networks (ANN, Papale and Valentini, 2003) has also been used and gave as resultant median African NEE of $-2.22 \mathrm{Pg} \mathrm{Cyr}^{-1}$ (5 and $95 \%$ percentile -3.35 and -1.08 , respectively). Median values reported for North Africa are $0.31 \mathrm{Pg} \mathrm{Cyr}^{-1}$ (percentile range $-1.02,0.42)$ and $-1.92 \mathrm{Pg} \mathrm{C} \mathrm{yr}^{-1}$ for sub-Saharan Africa (5 and $95 \% 10$ percentile $-2.43,-1.38$ ). The ANN approach is affected by the same uncertainty sources reported for the MTE results.

It is striking that there are no published field studies of NPP in African tropical forests where the major components of NPP have been directly measured. Malhi et al. (2011) conducted a review of NPP and its allocation in global tropical forests. For sites reporting woody production and canopy litterfall (i.e. neglecting root productivity), they found 33 sites in America, 21 in Asia, 12 in Hawaii, and none in Africa, despite Africa being the second largest rainforest continent. For sites that also reported fine-root productivity (and thus gave an estimate of total productivity), they found 35 sites worldwide, and again none in Africa. For lowland sites across the humid tropics, NPP ranged between 9 and $15 \mathrm{tC} \mathrm{ha}^{-1} \mathrm{yr}^{-1}$, and it is likely that NPP in African humid tropical forests is also within this range. In Amazonia, seasonal forests did not appear to have much lower NPP than dry forests, with low GPP compensated by a higher carbon use efficiency (NPP/GPP).

NPP values from savannas were compiled by Bombelli et al. (2009) and they range from 3.3 to $16.2 \mathrm{tC} \mathrm{ha}^{-1} \mathrm{yr}^{-1}$, with a mean value of $6.9 \mathrm{tC} \mathrm{ha}^{-1} \mathrm{yr}^{-1}$.

To date, no estimates of gross primary productivity (GPP) have been reported from African tropical forests sites (although estimates should be forthcoming from flux towers and intensive carbon cycling sites in the next 1 to $2 \mathrm{yr}$ ). Humid tropical forests in America and Asia report GPP in the range of 30 to $40 \mathrm{tCha}^{-1} \mathrm{yr}^{-1}$ (Malhi, 2012), with the mean towards the lower end of this range. Taking a lower end value of $30 \mathrm{tCha}^{-1} \mathrm{yr}^{-1}$ and multiplying by the area of African humid forests (about $2.33 \times 10^{6} \mathrm{~km}^{2}$ in the GLC data set) suggests a GPP of $7.0 \mathrm{PgC} \mathrm{yr}^{-1}$ in the humid forests. The African dry forests and woodlands are likely to have lower GPP (on the order of $20 \mathrm{tCha}^{-1} \mathrm{yr}^{-1}$, but are twice as extensive $\left(4.28 \times 10^{6} \mathrm{~km}^{2}\right)$ suggesting they contribute a further 8.6 $\mathrm{PgC}^{-1}$. Thus the total GPP of African forests and woodlands could be around $15.6 \mathrm{PgC} \mathrm{yr}^{-1}$, about $13 \%$ of global terrestrial GPP.

Field studies in Amazonia suggest that the carbon use efficiency (NPP/GPP) is around 0.35 in humid forests, and rises to 0.45 in dry forests (Malhi, unpublished analysis). Applying these values to the humid and dry forest areas as defined in this paper (see Sect. 3.2) gives a total NPP of 2.4 $\mathrm{Pg} \mathrm{C} \mathrm{yr}^{-1}$ in the humid forest zone and $3.9 \mathrm{Pg} \mathrm{Cyr}^{-1}$ in the dry forest/woodland zone (i.e. $6.3 \mathrm{Pg} \mathrm{C} \mathrm{yr}^{-1}$ ), about $10 \%$ of global terrestrial NPP, for the total forested zone.

The net change in biomass of tropical forests has been better reported, thanks to the pioneering work of the AfriTRON forest plot network ${ }^{10}$. Lewis et al. (2009) collected data from repeated surveys of 79 forest plots in central and West Africa, and reported a net biomass carbon sink of 0.63 (range $0.22-0.94) \mathrm{tC} \mathrm{ha}^{-1} \mathrm{yr}^{-1}$. This is very similar to the value of 0.45 (range 0.33-0.56) $\mathrm{tC} \mathrm{ha}^{-1} \mathrm{yr}^{-1}$ reported for 123 plots in Amazonia (Phillips et al., 2009), suggesting that a common driver, such as atmospheric $\mathrm{CO}_{2}$ fertilization, may be stimulating this biomass storage across the intact tropical forest biome. Scaling the data of Lewis et al. (2009) across the humid and dry forest biome, Malhi (2010) estimated a net biomass carbon sink of $0.31 \pm 0.15 \mathrm{Pg} \mathrm{Cyr}^{-1}$ in the African forest biome (i.e. $33 \%$ of the global tropical forest carbon sink and $16 \%$ of the global terrestrial carbon sink). This estimate does not incorporate any source or sink in the soils, and does not include the savanna biomes.

\subsection{DGVM-based estimates of gross fluxes and net ecosystem productivity}

Dynamic global vegetation models (DGVMs) simulate vegetation distribution, seasonally changing phenology, vegetation, soil carbon, water pools, and fluxes. Vegetation is classified into plant functional types, based on today's observed bioclimatic limits for establishment and survival, and characteristic plant growth strategies. Leaf carbon assimilation is mostly modelled following Farquhar et al. (1980) and Collatz et al. (1991, 1992), or some modification thereof, and coupled to the plant and soil water balance via stomatal conductance. Vegetation and ecosystem net productivity are determined by carbon losses through autotrophic and heterotrophic respiration. A set of allocation rules determines the carbon allocated to canopy growth, as well as to litter input into soils (for details see: Arneth et al., 2010b; Cramer et al., 1999; Prentice et al., 2007; Sitch et al., 2008).

Modelling tree-grass coexistence is important to correctly simulate the gradient from closed forests, through woodlands, savannas, and grasslands, and has been shown to be a challenge for many DGVMs (Cramer et al., 1999; Scheiter and Higgins, 2009). Whether this is due to the fact that many DGVMs have no representation or only have a highly simplified representation of fire and other episodic events, or

${ }^{10}$ (http://www.geog.leeds.ac.uk/projects/afritron) 
whether it reflects the need for a more generally improved representation of resource competition for light, nutrients, and water, or both, is unresolved. Bond et al. (2005) and Lehsten et al. (2014) demonstrated a largely improved agreement between estimates of African vegetation cover and DGVM output when fire disturbance was included in the simulations, especially in regions with intermediate amounts of annual precipitation. In both cases, inclusion of fire reduced the simulated extent of the tropical forest biome considerably and grasses and shrubs became more competitive in areas that are climatically suitable for dense tree cover.

A number of regionally (Scheiter and Higgins, 2009) and globally (Hickler et al., 2008; Smith et al., 2001) applicable DGVMs have begun to incorporate gap-model dynamics (Purves and Pacala, 2008) with a much more explicit representation of plant growth dynamics than in traditional DGVMs. For example, even resolving individuals or age cohorts in canopies. These types of models allow an improved analysis of the ecological effects of fire that is based on fire effects on vegetation structure and subsequent re-growth (Arneth et al., 2010a; Scheiter and Higgins, 2009), and the interactions with climate and the carbon cycle in Africa.

Only very few DGVM modelling studies have explored the African carbon cycle and its response to climate, $\mathrm{CO}_{2}$, and land-use change drivers. This is true despite the fact that savannas and tropical forests are highly productive ecosystems (Grace et al., 2006; Williams et al., 2007) and African carbon cycle dynamics play a potentially significant role for the global terrestrial carbon uptake and its interannual variability. Likewise, only limited observations exist to evaluate the quality of model output either on the local (e.g. eddy flux data) or continental (e.g. comparison with inversion results) level (Kutsch et al., 2008, 2011; Merbold et al., 2009; Veenendaal et al., 2004; Weber et al., 2009; Williams et al., 2007; Ziehn et al., 2010).

Applying the model ORCHIDEE with dynamic vegetation disabled, Ciais et al. (2009) simulated a source-sink shift in the continental $\mathrm{C}$ balance from $+0.14 \mathrm{Pg} \mathrm{C} \mathrm{yr}^{-1}$ in the 1980 s to $-0.13 \mathrm{Pg} \mathrm{Cyr}^{-1}$ in the $1990 \mathrm{~s}$, and interpreted this as the model's response to increasing $\mathrm{CO}_{2}$ concentrations, increasing precipitation in some regions, together with a decreasing trend in land-use change in their driving data. As the model simulation also attempted to account for $\mathrm{C}$ emissions associated with deforestation $\left(0.13 \mathrm{Pg} \mathrm{C} \mathrm{yr}^{-1}\right)$, the terrestrial sink in ecosystems not affected by land-use change was estimated approximately twice than that value. In a recent model-intercomparison of four ecosystem models (LPJDGVM, LPJ-GUESS, Jules, ORCHIDEE), annual averages of GPP for the period 1982 to 2006 varied from 17 to $40 \mathrm{Pg} \mathrm{Cyr}^{-1}$, while NPP over the same period was 10 to $17 \mathrm{Pg} \mathrm{Cyr}^{-1}$ (Weber et al., 2009). Estimates of net ecosystem production (NEP) were not provided in this study since the experimental set-up did not account for land-use changes, and since these numbers were derived for potential natural vegetation and were not scaled to the continent's actual land cover. However, some consensus seems to emerge in that, interannual variability in continental $\mathrm{C}$ uptake is driven more strongly by variability in photosynthesis than respiration, especially in the savannas in response to interannual variability in precipitation (Ciais et al., 2009; Weber et al., 2009).

Global DGVM data was provided by the TRENDY multimodel evaluation project as part of the Global Carbon Project (GCP). ${ }^{11}$ The DGVMs used in this study were CLM4CN (Thornton et al., 2007, 2009; Bonan and Levis, 2010; Lawrence et al., 2011), Hyland (Levy et al., 2004), LPJ (Sitch et al., 2003; Poulter et al., 2011), LPJ-Guess (Smith et al., 2001), O-CN (v0.74) (Zaehle and Friend, 2010), Orchidee (Krinner et al., 2005), SDGVM (Woodward et al., 1995; Woodward and Lomas, 2004), TRIFFID (Cox, 2001), and VEGAS (Zeng, 2003; Zeng et al., 2005). The models followed a common protocol (Sitch et al., 2013). ${ }^{12}$ DGVMs were applied with the merged CRU-NCEP climatology over the period 1901-2009, and global atmospheric $\mathrm{CO}_{2}$ was derived from ice core and NOAA monitoring station data, and provided at an annual resolution. Historical changes in land cover were not included in this simulation.

DGVM results are shown in Table 6 and Figs. 4 and 5. Generally, there is greater model agreement on simulated vegetation carbon and NPP than soil carbon stocks and the net biome flux. The model mean simulates a small sink for Africa over the period 1990-2009, although both the sign and magnitude of the flux varies among DGVMs. DGVMs simulate GPP, NPP, and a net sink over the period 19902010 of $28.16 \pm 5.94 \mathrm{Pg} \mathrm{Cyr}^{-1}, 13.27 \pm 3.25 \mathrm{Pg} \mathrm{C} \mathrm{yr}^{-1}$ and $0.41 \pm 0.31 \mathrm{Pg} \mathrm{C} \mathrm{yr}^{-1}$, respectively.

\subsection{Fluxes resulting from land-use change (mainly deforestation)}

In this section, we provide a new estimate of carbon emission from land-use changes in Africa. These are mainly deforestation, although we attempt to estimate also forest degradation and the role of agroforestry systems. Annual emissions of carbon from land use (e.g. timber harvest) and land-use change (e.g. conversion of forest to cropland) were determined as described in Houghton and Hackler (2006) except that the calculations were updated here with the most recent FAO data on changes in forest area (FAO, 2010). Briefly, the analysis considered four sub-regions within sub-Saharan Africa: western, eastern, central, and southern Africa. Land uses included permanent croplands (cultivated lands), pastures, tree plantations, industrial wood harvest, and shifting cultivation (a rotational land use with alternating cropping and fallow, in which trees regrow until being cleared again for the cropping period). Fuelwood harvest was not explicitly included in the analysis, but it was implicitly included, in part, because both shifting cultivation and the conversion of

\footnotetext{
${ }^{11}$ http://dgvm.ceh.ac.uk/

12 ibid
} 
Table 6. DGVM average carbon pools (PgC) and fluxes

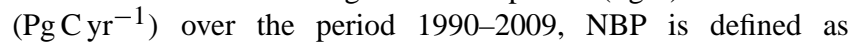
$\mathrm{NBP}=\mathrm{NPP}-\mathrm{RH}-$ wildfire Flux $(*$ note LPJ has a grazing term in the NBP calculation).

\begin{tabular}{lrrrrrr}
\hline DGVM & VegC & SoilC & NPP & GPP & Wildfire & NBP \\
\hline CLM4CN & 96.27 & 87.48 & 9.25 & 25.33 & 0.60 & 0.16 \\
Hyland & 181.44 & 240.95 & 20.46 & 40.91 & - & 1.09 \\
LPJ & 82.16 & 94.93 & 11.18 & 24.91 & 0.64 & 0.24 \\
LPJ-GUESS & 92.14 & 103.36 & 12.21 & 20.61 & 1.47 & 0.38 \\
OCN & 106.03 & 169.78 & 11.26 & 25.92 & - & 0.30 \\
ORCHIDEE & 98.69 & 236.52 & 15.77 & 32.24 & - & 0.60 \\
SDGVM & 66.70 & 193.48 & 12.70 & 24.07 & 1.27 & 0.44 \\
TRIFFID & 127.68 & 120.56 & 13.89 & 28.95 & - & 0.50 \\
VEGAS & 129.08 & 259.53 & 12.7 & 30.46 & - & -0.01 \\
Mean Model & 108.91 & 167.40 & 13.27 & 28.16 & 1.00 & 0.41 \\
St. Dev. & 33.67 & 68.28 & 3.25 & 5.94 & 0.44 & 0.31 \\
\hline
\end{tabular}

forests to croplands and pastures result in large emissions of carbon from burning, some of which take place via collection and burning of fuelwood. Deforestation rates between 1980 and 2010 (FAO, 2010) expanded either cropland or pasture areas based on data from FAOSTAT (2009). If net forest area decreased by more than the net expansion of croplands and pastures, the difference was assumed to be deforestation for shifting cultivation (Houghton and Hackler, 2006). Between 1900 and 1980 rates of land-use change were obtained from various historical accounts (Houghton and Hackler, 2006). Annual sources and sinks of carbon from land-use change were calculated with a bookkeeping model (Houghton and Hackler, 2006). In the model, annual rates of land-use change initiated changes in the carbon density of the ecosystems affected. The changes in carbon density were defined empirically for four pools (living vegetation, coarse woody debris, harvested wood products, and soils). For example, the harvest of wood redistributed the carbon initially in living vegetation among living, dead, and product pools. Following harvest, the living pool accumulated carbon (forest regrowth); the dead pool decayed exponentially, and the wood products decayed at rates corresponding to end use (for example, fuelwood, timber). A different set of pool changes were defined for conversion of forest to cropland. The empirically determined changes in carbon density varied by ecosystem type and by land use. They did not vary in response to rising $\mathrm{CO}_{2}$ or changes in climate. Ecosystems not cleared or harvested did not contribute to land-use emissions. Thus, each year, the pools of carbon on a hectare either gained or lost carbon, defining the annual sources and sinks of carbon for that hectare; and, when summed, annual fluxes were obtained for each type of land use, each type of ecosystem, the region, or the continent. We assumed that following cultivation, native soils lost $25 \%$ of the organic carbon in the top metre. Forest areas and biomass densities at the beginning of the analysis (1850) were chosen so that the areas and average biomass densities in 2010 matched those given by FAO (2010).

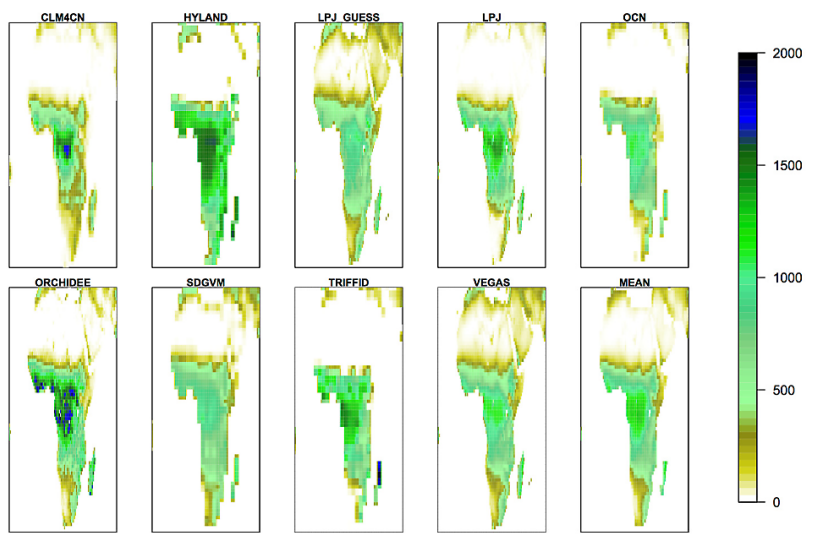

Fig. 4. Average net primary productivity (NPP) for each DGVM and model mean over the period 1990-2009, units, $\mathrm{g} \mathrm{C} \mathrm{m}^{-2} \mathrm{yr}^{-1}$ (from Sitch et al., 2014).

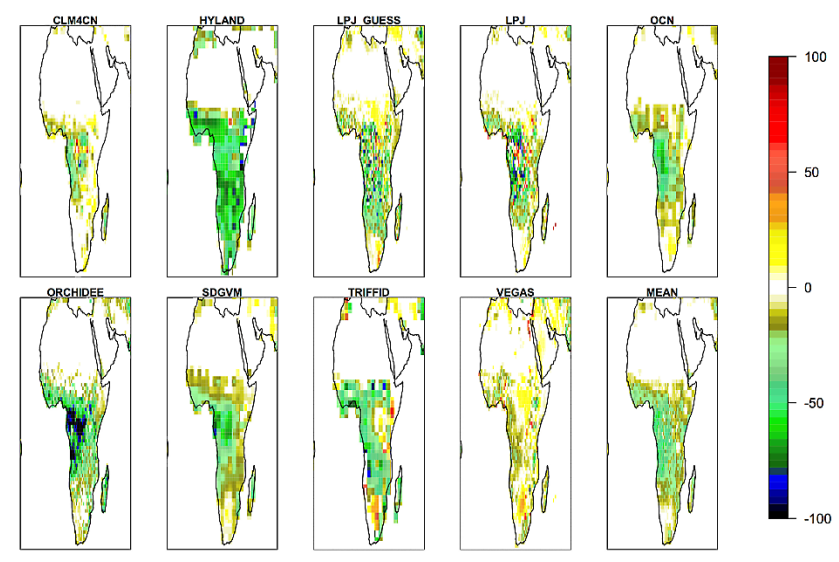

Fig. 5. Average net biome productivity (NBP) for each DGVM and model mean over the period 1990-2009, units, $\mathrm{g} \mathrm{C} \mathrm{m}^{-2} \mathrm{yr}^{-1}$.

Over the last $100 \mathrm{yr}$, forest areas declined as a result of conversion to agricultural lands, and carbon densities declined as a result of wood harvest (degradation). For all of sub-Saharan Africa, the net emissions of carbon from landuse and land-cover change averaged $320 \pm 50 \mathrm{Tg} \mathrm{C} \mathrm{yr}^{-1}$ over the period 1990 to 2009 . The rate since 1980 was nearly constant for the entire region, but emissions increased slightly in eastern, western, and southern Africa and decreased in central Africa (Table 7). The largest emissions were from western Africa $\left(107 \mathrm{Tg} \mathrm{C} \mathrm{yr}^{-1}\right)$ and the lowest were in eastern and central Africa $\left(\sim 60 \mathrm{Tg} \mathrm{C} \mathrm{yr}^{-1}\right)$. The land uses contributing to these emissions (in descending order of magnitude) were: expansion of croplands, shifting cultivation, pastures, and industrial wood harvest (Table 7). The establishment of tree plantations was not a significant sink in any region. Again, the major drivers varied among sub-regions. Expanding croplands were most important in western Africa, shifting cultivation was most important in central Africa, and industrial wood harvest was most important in central and southern 
Table 7. Sources (+) and sinks (-) of carbon $\left(\mathrm{Tg} \mathrm{C} \mathrm{yr}^{-1}\right)$ from different types of land use in regions of sub-Saharan Africa (average annual net flux).

\begin{tabular}{|c|c|c|c|c|c|c|c|c|}
\hline & Period & Croplands & Pasture & Afforest. & $\begin{array}{l}\text { Indust. } \\
\text { harvest }\end{array}$ & $\begin{array}{r}\text { Fuelwood } \\
\text { harvest }\end{array}$ & $\begin{array}{r}\text { Shifting } \\
\text { cult. }\end{array}$ & Total \\
\hline All sub- & 1980-1989 & 101 & 25 & -3 & 23 & 0 & 167 & 314 \\
\hline Saharan & 1990-1999 & 154 & 65 & -2 & 32 & 0 & 67 & 317 \\
\hline \multirow[t]{2}{*}{ Africa } & 2000-2009 & 164 & 34 & -2 & 38 & 0 & 89 & 323 \\
\hline & 1990-2009 & 159 & 49 & -2 & 35 & 0 & 78 & 320 \\
\hline East & 1980-1989 & 26 & 10 & -1 & 3 & 0 & 11 & 47 \\
\hline \multirow[t]{3}{*}{ Africa } & 1990-1999 & 27 & 25 & -1 & 5 & 0 & 6 & 62 \\
\hline & 2000-2009 & 45 & 6 & 0 & 6 & 0 & 2 & 58 \\
\hline & 1990-2009 & 36 & 16 & -1 & 5 & 0 & 4 & 60 \\
\hline West & 1980-1989 & 42 & 9 & 0 & 9 & 0 & 18 & 77 \\
\hline \multirow[t]{3}{*}{ Africa } & 1990-1999 & 93 & 3 & 0 & 11 & 0 & 0 & 108 \\
\hline & 2000-2009 & 93 & 1 & -1 & 13 & 0 & 1 & 106 \\
\hline & 1990-2009 & 93 & 2 & -1 & 12 & 0 & 0 & 107 \\
\hline Southern & 1980-1989 & 17 & 7 & -1 & 4 & 0 & 43 & 71 \\
\hline \multirow[t]{3}{*}{ Africa } & 1990-1999 & 31 & 35 & -1 & 7 & 0 & 10 & 82 \\
\hline & 2000-2009 & 22 & 26 & 0 & 8 & 0 & 40 & 96 \\
\hline & 1990-2009 & 27 & 31 & 0 & 8 & 0 & 25 & 89 \\
\hline Central & 1980-1989 & 17 & 0 & 0 & 7 & 0 & 95 & 119 \\
\hline \multirow[t]{3}{*}{ Africa } & 1990-1999 & 3 & 1 & 0 & 9 & 0 & 51 & 64 \\
\hline & 2000-2009 & 4 & 1 & 0 & 10 & 0 & 47 & 62 \\
\hline & 1990-2009 & 3 & 1 & 0 & 10 & 0 & 49 & 63 \\
\hline
\end{tabular}

Africa. The emissions of carbon from land-use and landcover change in sub-Saharan Africa over the period 1990 to 2009 accounts for about a third of global emissions from land use (Friedlingstein et al., 2010). An independent study of shifting cultivation supports the importance of central Africa (Silva et al., 2011), and in fact, the expansion of industrial logging in central Africa was recently documented (Laporte et al., 2007). Somewhat unusual for Africa is the observation that the areas of primary (untouched) forest, given by FAO (2010), are much smaller than the areas of primary forest determined here on the basis of land use. The total forest areas match, but, according to FAO, most of the current forests are secondary or managed forests, while according to the rates of land use documented in this study, most of them are primary forests.

This discrepancy between FAO estimates of primary forests and ours is difficult to explain at continental scale. Recent studies highlight the importance of forest degradation and conversion to agroforestry systems as two potential underestimated drivers of understocking of primary forests. Most analysis reported deforestation as the land-use change between forest to any other use, such as crop, pasture or even urban areas. Very few studies report the impact of selective logging on forest carbon stocks. Often, the intensity of the disturbance caused by selective logging is regarded as negli- gible or even positive for the ecosystem and, "sustainable", when supported by international certifications. In the past, the intensity of the disturbance caused by selective logging was often quantified as the number of felled trees or type of machinery used for the construction of access roads and exploitation trails. These impacts have been assessed as minor disturbances by previous studies (Deckker and De Graaf, 2003). We present here some results from a study on the impact of selective logging in African tropical forests on biomass and biodiversity losses, studied by co-authors of this paper (Cazzolla Gatti et al., 2014). The study sites selected were tropical forest areas located in West Africa along the border between Ghana and Ivory Coast (Bia National Park and surrounding areas) and Sierra Leone and Liberia (Gola National Park), and in central Africa, within the Congo River basin, on the border between Cameroon and Central African Republic (Lobèkè National Park and surrounding areas). African tropical forests biomass was estimated from dendrometric data collected in 150 plots of $500 \mathrm{~m}^{2}$ each, subjected to different management (unmanaged/old growth; selectively logged; clear-cut). The normalized mean level of biomass (divided by area and number of individuals within each plot) of primary forest was compared to that of a selectively and clear-cut one. It was observed that even if the levels of biomass in forests subjected to selective logging 
are significantly lower than those of primary forests (even if there is a removal of very few trees per hectare); this reduction is more evident $30 \mathrm{yr}$ after logging and not after $20 \mathrm{yr}$. The results showed a loss of carbon between 20 and $51 \%$ of the initial primary forest value after $20 \mathrm{yr}$ from selective logging and 24 to $72 \%$ after a period of $30 \mathrm{yr}$. These figures highlight the significant loss of carbon even without changes in the main dominant land use (forest).

Another source of uncertainty is the role of conversion of primary forests into plantations in terms of carbon stocks dynamics. We present here some preliminary results from coauthors of this paper (Grieco et al., 2014) who analysed the impact of forest conversion to plantation in a tropical rainforest area of West Ghana. The results show that the land-use change leads to a significant loss of $\mathrm{C}$ stock when passing from primary forest to any of the considered plantations (coconut, rubber, oil palm, cocoa, mixed).

According to Gibbs et al. (2010), nearly $60 \%$ of new agricultural land in Africa was derived from intact forests. Africa had a net forest loss of $3.4 \mathrm{Mha}$ annually for the period 2000 to 2010 (FRA, 2010). Assuming that $60 \%$ of these areas were converted into agricultural land we estimated that 2.0 Mha was yearly converted from forest to agriculture. Assuming that $12.4 \%$ of agricultural land in Africa is agroforestry with tree cover percentage $>30 \%$ (Zomer et al., 2009), this results in a rough estimation of 253000 ha of agroforestry land derived from deforestation of pristine forests in Africa every year. Considering a mean annual $\mathrm{C}$ loss per hectare of $4.1 \pm 3.8 \mathrm{MgC}$, due to conversion of forest into tree crop plantations (Grieco et al., 2014), this would cause a significant annual loss of carbon, in the order of up to $1.0 \mathrm{Tg} \mathrm{C}$ if extrapolated to the entire African continent.

These results show that, although deforestation remains the main driver of carbon losses from land-use change, forest degradation and conversion, though lower and highly uncertain, are likely to increase carbon losses and need to be taken into account particularly considering the future economic development of Africa.

\subsection{Wild fires and domestic biomass burning}

Fires are additional to heterotrophic respiration and herbivory in consuming carbon that has been sequestered by photosynthesis. The amount of carbon combusted through "wild" fires (i.e. excluding the burning of fuelwood or residues, but including managed burning of natural vegetation) depends on the fire frequency, the amount of biomass available, the fraction of biomass that is exposed to fire is actually combusted (the combustion completeness), and the post-fire tree mortality and regrowth rates. In most African ecosystems, especially those that experience frequent fires, fires mostly consume the herbaceous vegetation while a thick bark protects the trees. In addition to these fires that occur in the landscape, fire is used domestically for cooking and heating purposes. We will refer to these fires as domestic fires.
In general, fires are not a net source of $\mathrm{CO}_{2}$ over decadal timescales unless fire is used in the deforestation process or if areas see an increase in the fire frequency. Humans ignite most fires in Africa (Archibald et al., 2010) and climate limits the occurrence of fires in arid regions (due to a lack of fuel build-up) and in areas that see frequent rainfall even in the dry season (van Wilgen and Scholes, 1997; van der Werf et al., 2008). In between these extremes, the importance of climate is relatively minor.

Archibald et al. (2011), for example, found that while climate could explain about $40 \%$ of the variability in interannual variability in burned area in protected areas in several countries in Africa, outside these areas, it could not account for much of the variability, highlighting the human control over fire regimes. This strong human component has not necessarily led to an increase in emissions over the past decades as often suggested; human interference with the landscape has led to a more patchy landscape where fuel beds are not continuous (Archibald et al., 2010), while more frequent grazing may have led to less fuel in general.

A recent review of emissions from all types of fires in Africa (wildfires, domestic fuelwood and fire associated with land-use change) is provided by Scholes et al. (2011). The authors concluded, based on a synthesis of many sources, that the total annual consumption of biomass is $1.4 \pm$ $0.2 \mathrm{Pg} \mathrm{DM} \mathrm{yr}^{-1}$ (the uncertainty is the $95 \%$ confidence interval), which corresponds to about $0.7 \pm 0.1 \mathrm{Pg} \mathrm{C} \mathrm{yr}^{-1}$. They further estimated that $57 \%$ of this is due to wildfires, mostly in savannas, $36 \%$ is domestic wood and charcoal, $3 \%$ is associated with land-use change, and $4 \%$ is the burning of crop residues.

Currently, the most accurate burned area estimates for Africa are derived from the MODIS sensors (Giglio et al., 2009, 2010; Roy et al., 2003). The two different algorithms used indicate that total annual burned area is on average $250 \mathrm{Mha} \mathrm{yr}^{-1}$ over the past decade, almost evenly split between Africa north and Africa south of the equator. This is almost $70 \%$ of the global total burned area. Since a fire has to consume at least $50 \%$ of the $500 \mathrm{~m} \times 500 \mathrm{~m}$ grid cell (but most often more) to be detected as burned area, the burned area estimates are likely an underestimate, due to missing small fires, for example those in agricultural areas.

Converting burned area estimates to emissions requires the use of models that take into account the variable fuel consumption, due to landscape heterogeneity and changes in meteorological or climatic conditions that impact combustion completeness. Over larger scales, probably the most frequently used data set is the Global Fire Emissions Database (GFED), which combines burned area from Giglio et al. (2010) with the satellite-driven Carnegie-Ames-Stanford approach biogeochemical model that estimates fuel loads based on carbon input from net primary production (NPP), and losses through heterotrophic respiration, herbivory, fuelwood collection, and fires with a monthly timestep on a $0.5 \times 0.5$ grid (van der Werf et al., 2010). 
Total annual carbon emissions estimates for Africa according to GFED were $1.03 \pm 0.22 \mathrm{Pg} \mathrm{C} \mathrm{yr}^{-1}$, averaged over the

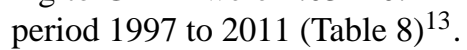

About $90 \%$ of these emissions originated from savanna and woodland burning, with a smaller role from forest and deforestation fires. Since there is relatively more woodland burning in Africa south of the equator, mean fuel consumption was somewhat higher here $\left(\sim 450 \mathrm{~g} \mathrm{C} \mathrm{m}^{-2}\right.$ burned $)$ than in northern Africa $\left(\sim 380 \mathrm{~g} \mathrm{C} \mathrm{m}^{-2}\right.$ burned) and total emissions were thus also somewhat higher in the Southern Hemisphere of Africa. These fuel consumption estimates are higher than most field measurements (Scholes et al., 2011) and GFED may be biased high, possibly partly balancing the underestimation due to missing small fires.

Fire emissions estimates are uncertain due to uncertainties in burned area, fuel loads, fire-combustion completeness, and emission factors. A promising new approach uses the fire radiative power (FRP) measured by satellite, which removes much of the uncertainty in fuel load and combustion completeness, since it directly estimates the fuel combusted. Wooster et al. (2005) showed a direct relation between timeand-space integrated FRP (yielding fire radiative energy, FRE) and biomass combusted, and both MODIS (Ellicott et al., 2009) and SEVERI (Roberts and Wooster, 2008) data has been used to calculate emissions over the African continent. These estimates are about a factor 3 lower than those from GFED, but when combined with burned area estimates, they yield a better correspondence with fuel consumption measurements in the field than those from GFED. At the same time, combining measurements of fire-emitted gases from several sources with inverse modeling techniques yielded better agreement with modeled fire emissions (AMMABB) in West Africa when the L3JRC burned area product (Tansey et al., 2008) used in this database was boosted by a factor 2 and 1.67 for the land cover classes open broadleaf deciduous forest and deciduous shrubs, respectively (Liousse et al., 2010). This emissions' estimate is about twice as high as GFED although part of the discrepancy originated from using different emission factors, so estimate carbon emissions are more similar. Using the L3JRC product, Lehsten et al. (2009) estimated emissions for Africa to be $0.7 \mathrm{Pg} \mathrm{C} \mathrm{yr}^{-1}$ with similar fuel consumption as GFED. These divergent results indicate that fire emissions estimates are still uncertain.

On a global scale, Africa accounted for $72 \%$ of global burned area, $52 \%$ of global carbon emissions, $44 \%$ of CO emissions and $36 \%$ of $\mathrm{CH}_{4}$ emissions (van der Werf et al., 2010; Scholes et al., 2011). The smaller contribution of carbon and trace gas emissions is related to the dominance of savanna burning with relatively low fuels and clean combustion.

\footnotetext{
${ }^{13}$ http://www.falw.vu/gwerf/GFED/GFED3/tables/emis_C_ absolute.txt
}

Table 8. Fire emissions characteristics for Africa based on 19972011 GFED data.

\begin{tabular}{lcc}
\hline & North of equator & South of equator \\
\hline $\begin{array}{l}\text { Mean annual emissions } \\
\left(\text { Pg Cyr }^{-1}\right)\end{array}$ & $0.469 \pm 0.094$ & $0.562 \pm 0.112$ \\
$\begin{array}{l}\text { Coefficient of variation } \\
(\%)\end{array}$ & 15 & 9 \\
$\begin{array}{l}\text { Range } \\
(\text { Pg C) }\end{array}$ & 0.221 & 0.199 \\
$\begin{array}{l}\text { Fuel consumption } \\
\left(\mathrm{gCm}^{-2}\right)\end{array}$ & 371 & 446 \\
\hline
\end{tabular}

\subsection{Lateral fluxes through river flows}

Significant amounts of carbon are transported from terrestrial ecosystems to oceans and other places, mainly through river flow, but also through agricultural and wood product transport. Although locally lateral transport may not be a very large flux, the sum of individual contributions is significant in the calculation of regional carbon budgets (Raymond et al., 2008). To estimate the land to ocean carbon flux and transport to endorheic regions, we used the 21 ocean coastline $\left(26212740 \mathrm{~km}^{2}\right)$ and 8 endorheic $\left(3706207 \mathrm{~km}^{2}\right)$ segments with their corresponding river catchments for Africa as described by the COSCAT database (Meybeck et al., 2006). The lateral transport of carbon to the coast was estimated at the river basin scale using the Global Nutrient Export from WaterSheds (NEWS) model framework (Mayorga et al., 2010), including NEWS basin areas. The carbon species models are hybrid empirically and conceptually based models that include single and multiple linear regressions developed by the NEWS effort and Hartmann et al. (2009), and single-regression relationships assembled from the literature. Modeled dissolved and particulate organic carbon (DOC and POC) loads used here (Mayorga et al., 2010) were generated largely using drivers corresponding to the year 2000, including observed hydro-climatological forcings, though some parameters and the observed loads are based on data spanning the previous two decades. Total suspended sediment (TSS) exports were also estimated by NEWS. Dissolved inorganic carbon (DIC) estimates correspond to weatheringderived bicarbonate exports and do not include $\mathrm{CO}_{2}$ supersaturation; the statistical relationships developed by Hartmann et al. (2009) were adjusted in highly weathered tropical soils (ferralsols) to $25 \%$ of the modeled values found in Hartmann et al. (2009) to account for overestimates relative to observed river exports (as suggested in Hartmann and Moosdorf, 2011); adjusted grid-cell scale exports were aggregated to the basin scale using NEWS basin definitions (Mayorga et al., 2010), then reduced by applying a NEWS-based, basin scale consumptive water removal factor from irrigation withdrawals (Mayorga et al., 2010). DIC modeled estimates represent approximately 1970 to 2000 . Overall, carbon loads 
may be characterized as representing general conditions for the period 1980 to 2000. Carbon, sediment, and water exports were aggregated from the river basin scale to corresponding COSCAT regions. It is worth pointing out that Africa is under-represented in the data sets used to generate the regressions relationships.

Combining river gauges data (Fekete et al., 2002) and modeling, it was obtained that the total amount of water discharge is $4285 \mathrm{~km}^{3} \mathrm{yr}^{-1}\left(0.16 \mathrm{~m} \mathrm{yr}^{-1}\right)$ to the coast and $268 \mathrm{~km}^{2} \mathrm{yr}^{-1}\left(0.07 \mathrm{~m} \mathrm{yr}^{-1}\right)$ to endorheic regions. These water yields are approximately an half of the global average of $0.32 \mathrm{~m} \mathrm{yr}^{-1}$ (Raymond et al., 2013). Furthermore, although the endorheic segments make up $12.4 \%$ of the land mass of Africa, they are responsible for only $5.9 \%$ of the water discharge. DIC, DOC, and POC fluxes to the ocean are $29.40,17.90$, and $15.70 \mathrm{Tg} \mathrm{Cyr}^{-1}$, respectively, or yields of $1.12,0.68$ and $0.60 \mathrm{~g} \mathrm{~m}^{-2}$ of land mass draining to the ocean. These global yields are also approximately an half of the global averages. Thus, the yields of Africa are low globally due to low water throughput.

The Congo River dominates the dissolved fluxes from the African continent to the ocean, making up approximately $35 \%$ of the water and $40 \%$ of the DOC and DIC. The percent contribution of the Congo to POC fluxes are only $14 \%$. Approximately 73,26 , and $1 \%$ of the dissolved carbon fluxes are to the Atlantic, Indian, and Mediterranean/Black seas, respectively. For particulate organic carbon, approximately 66,32 , and $2 \%$ of the fluxes are to the Atlantic, Indian, and Mediterranean/Black seas, respectively.

\section{9 $\mathrm{N}_{2} \mathrm{O}$ and $\mathrm{CH}_{4}$ fluxes from biogenic sources and fires}

Although, excluding water vapor, $\mathrm{N}_{2} \mathrm{O}$ and $\mathrm{CH}_{4}$ are the second and third most important greenhouse gases after $\mathrm{CO}_{2}$ in terms of atmospheric concentration and radiative forcing effect on climate, studies on biogenic fluxes of both gases in African ecosystems are quite scanty and scaling up and yearly extrapolation estimates are strongly affected by high uncertainty. $\mathrm{N}_{2} \mathrm{O}$ is mainly driven by availability of $\mathrm{N}$ and its production is favored by low oxygen tension. However, prolonged anoxic conditions lead to further $\mathrm{N}_{2} \mathrm{O}$ reduction to $\mathrm{N}_{2}$, as it occurs in wetlands. In terrestrial ecosystems, the most favorable conditions for $\mathrm{N}_{2} \mathrm{O}$ production are when soil water filled pore space is between 60 and $90 \%$ (Davidson, 1993), which more frequently occurs in humid tropical forests (Castaldi et al., 2013), and in savannas during the rainy season (Castaldi et al., 2006), in particular during its onset. In arid and semiarid areas, conditions are generally limiting for significant $\mathrm{N}_{2} \mathrm{O}$ production. In cropland areas, high $\mathrm{N}_{2} \mathrm{O}$ emissions are favored by the addition of extra $\mathrm{N}$ inputs (organic or mineral $\mathrm{N}$ ), but only at suitable soil water content can high $\mathrm{N}_{2} \mathrm{O}$ fluxes be expected.

The emissions of $\mathrm{N}_{2} \mathrm{O}$ from natural ecosystems were calculated from an empirical sigmoidal relationship $\left(R^{2}=0.72\right.$, $P<0.001, n=63$ ), between total annual $\mathrm{N}_{2} \mathrm{O}$ emission and total annual rainfall using flux data reported by Castaldi et al. $(2006,2010)$ for seasonally dry ecosystems and by Castaldi et al. (2013) for humid tropics. At continental level, this source represents $33.4 \%$ of the total, (Table 9) with humid tropical forests contributing to $90 \%$ of this fraction. In these ecosystems, the environmental conditions allow for high productivity and high organic matter inputs to the soil, which, favored by high soil humidity and temperature during most of the year, create a fast flow of $\mathrm{N}$ in the ecosystem. This can support high mineralization, nitrification, and denitrification rates and $\mathrm{N}_{2} \mathrm{O}$ production (Castaldi et al., 2013).

The second most important source is represented by agricultural ecosystems (38.4\%, Table 9), where the source of extra $\mathrm{N}$ to the soil derives from both fertilizer use and husbandry, the latter prevailing over the former in most areas (Potter et al., 2010).

In cultivated areas derived from quite recently deforested areas, a further input of extra $\mathrm{N}$ originates from mineralization of the organic matter left on the ground (slash, wood) after the conversion, and by the mineralization of soil organic matter, which is stimulated by management practices and disturbance.

Several studies show that during the first years following deforestation, the site emits more $\mathrm{N}_{2} \mathrm{O}$ than the original forest (control site). This extra flux of $\mathrm{N}_{2} \mathrm{O}$ decreases exponentially with time and within 20 to $40 \mathrm{yr}$, depending on the study, the deforested site baseline flux levels off stabilizing around annual $\mathrm{N}_{2} \mathrm{O}$ values lower (around $50 \%$ ) than the original forest. An exponential decay fitting equation $\left(R^{2}=0.45\right.$, $P=0.01, n=16$ ) was applied to data recalculated from available studies on deforestation (Table 9) to calculate the background annual $\mathrm{N}_{2} \mathrm{O}$ emission in agricultural areas for the African continent, assuming that all crop areas derived from forest clearing. To define the year of land-use change yearly, maps of land use were derived from the data set on Global Cropland and Pasture Data by Ramankutty and Foley (1999). This source is estimated to be $88.8 \mathrm{Gg} \mathrm{N}_{2} \mathrm{O} \mathrm{yr}^{-1}$, thus about $2.7 \%$ of the total $\mathrm{N}_{2} \mathrm{O}$ budget.

Indirect sources of $\mathrm{N}_{2} \mathrm{O}$ are emissions associated with $\mathrm{N}$ deposition and $\mathrm{N}$ export from land to rivers (Table 9). The former are dominated by "fire generated $\mathrm{N}$ compounds" and at a minor extent by agricultural practices. A very low contribution comes from anthropogenic pollution (Dentener, 2006). $\mathrm{N}$ export and consequent-derived $\mathrm{N}_{2} \mathrm{O}$ emissions are subject to an enormous uncertainty associated both to $\mathrm{N}$ export quantification and emission coefficient estimates (Van Drecht et al., 2003; IPCC, 1997). Another relevant source is represented by direct $\mathrm{N}_{2} \mathrm{O}$ emissions from fires (natural and agricultural), which account for $17.1 \%$ of the total annual $\mathrm{N}_{2} \mathrm{O}$ emission to the atmosphere from the African continent.

More biological processes contribute to the continental budget of $\mathrm{CH}_{4}$. Biogenic $\mathrm{CH}_{4}$ is produced by metabolic activity of methanotrophic bacteria, which transform fermentation products, formed by other microorganisms, in $\mathrm{CH}_{4}$ when conditions are strictly anaerobic. $\mathrm{CH}_{4}$ production occurs in 
Table 9. Emissions of $\mathrm{N}_{2} \mathrm{O}$ associated to biogenic sources and fires in the African continent.

\begin{tabular}{|c|c|c|}
\hline & $\begin{array}{l}\mathrm{N}_{2} \mathrm{O} \text { emissions at } \\
\text { continental level } \\
\left(\mathrm{Gg} \mathrm{N}_{2} \mathrm{O} \mathrm{yr}^{-1}\right)\end{array}$ & $\begin{array}{l}\text { Contribution }(\%) \text { of } \\
\text { single sources to total } \\
\text { continental emissions }\end{array}$ \\
\hline \multicolumn{3}{|l|}{ Soil emissions } \\
\hline Natural ecosystems & $1131.9^{\mathrm{a}} \pm 905$ & $34.4 \%$ \\
\hline Agricultural practices and husbandry & $1262.3^{\mathrm{b}} \pm 883$ & $38.4 \%$ \\
\hline Deforestation effect on soil (background flux) & $88.6^{\mathrm{c}} \pm 62.0$ & $2.7 \%$ \\
\hline \multicolumn{3}{|l|}{ Other direct and indirect sources } \\
\hline $\mathrm{N}$ depositions & $123.8^{\mathrm{d}}$ & $3.8 \%$ \\
\hline $\mathrm{N}$ leaching derived & $117^{\mathrm{e}}(9-566)^{\mathrm{f}}$ & $3.6 \%$ \\
\hline Emissions from fire & $562^{\mathrm{g}}$ & $17.1 \%$ \\
\hline \multicolumn{3}{|l|}{ Total emissions } \\
\hline $\mathrm{Tg} \mathrm{N}_{2} \mathrm{O} \mathrm{yr}^{-1}$ & $3.3 \pm 1.3$ & \\
\hline $\mathrm{TgCO}_{2}$-eq & $983 \pm 41$ & \\
\hline $\begin{array}{l}\text { a Data derived from an empirical relationship between annual } \\
\text { 2014). } \\
\text { b Modeled for sub-Saharan Africa after Bouwman et al. (2002 } \\
\text { Edgar } 4.1 \text { data for natural emissions from countries of North A } \\
\text { c empirical equation base on published data (Keller, 1993; We } \\
\text { Melillo et al., 2001; Neill et al., 2005; Verchot et al., 2006; Ma } \\
\text { d N inputs derived from Dentener et al. (2006) and EFs from I } \\
\text { e N export from Van Drecht et al. (2003) and IPCC (2007) EF } \\
\text { f Error range as reported by IPCC (2007). } \\
\text { g Edgar 4.1. }\end{array}$ & $\begin{array}{l}\text { tal emissions and total ar } \\
\mathrm{N} \text { input in agroecosysten } \\
\text { rica, based on IPCC meth } \\
\mathrm{z} \text { et al., 1998; Verchot et } \\
\text { anda et al., 2010). } \\
\text { CC (2007). }\end{array}$ & $\begin{array}{l}\text { ual rainfall (Castaldi et al., } \\
\text { derived by Potter et al. (2010), } \\
\text { dology (Hickman et al., 2011). } \\
\text { 1999; Potter et al., 2001; }\end{array}$ \\
\hline
\end{tabular}

wetlands and saturated soils, anaerobic hotspots in unsaturated soils, mostly associated to organic input and intense mineralization activity. $\mathrm{CH}_{4}$ is also produced by enteric fermentation in the rumen and hindgut of animals, being greatest in ruminants, and in particular in domesticated ones (Crutzen et al., 1986). However, several invertebrates also host methanogenic organisms in their gut, termites being the most relevant in terms of total biomass and $\mathrm{CH}_{4}$ emission rates. $\mathrm{CH}_{4}$ is oxidated by chemoautotrophic aerobic bacteria. Most typically methanotrophic activity occurs in wellaerated soils, but it also contributes to the net ecosystem exchange of $\mathrm{CH}_{4}$ in the column of water and in saturated soils when sufficient oxygen is available. Taking into account $\mathrm{CH}_{4}$ biological sources and sinks, the African $\mathrm{CH}_{4}$ budget is dominated by emitting processes, natural wetlands and animal husbandry being the most relevant sources (49 and $25.5 \%$, respectively, Table 10). Wetlands emissions are, however, characterized by high uncertainty due to widely differing estimates from the few available studies (Table 10). Rice paddies represent a minor source in Africa due to their smaller extent compared to other tropical countries (Table 10). Tropical humid forests and pastures are a weak net $\mathrm{CH}_{4}$ sources. In the former, net $\mathrm{CH}_{4}$ emissions in lowland areas are balanced by the net $\mathrm{CH}_{4}$ sink of upland areas, whereas pastures are generally net sources of $\mathrm{CH}_{4}$ during the wettest months (Castaldi et al., 2006). Soils in seasonally dry forests and savannas are instead a net $\mathrm{CH}_{4}$ sink (Castaldi et al., 2006), which, given the wide extension of these ecosystems, coun- terbalances the small source of $\mathrm{CH}_{4}$ from humid forests, resulting, at continental level, in a small net $\mathrm{CH}_{4}$ sink (Table 10). Emissions from fires represent the third largest $\mathrm{CH}_{4}$ source at continental level, due to the wide surface of territory, which gets burned every year, especially in arid and seasonally dry areas. Estimates of $\mathrm{CH}_{4}$ emissions from termites are highly variable depending on the proposed approach for calculations (from 2.5 to $6.9 \mathrm{Tg} \mathrm{CH}_{4} \mathrm{yr}^{-1}$, Table 10). The number of studies which allow for good upscaling are scanty, so that all proposed estimates are based on very rough extrapolations. Biogenic sources and fires overall lead to an average total emissions of $66 \mathrm{Tg} \mathrm{CH}_{4} \mathrm{yr}^{-1}$. In terms of $\mathrm{CO}_{2}$ equivalents, this would correspond to an average emissions of $1.64 \mathrm{Pg} \mathrm{CO}_{2}$-eq $\mathrm{yr}^{-1}$.

\section{Interannual variability}

The African continent is responsible for a large fraction of the global carbon cycle's interannual variability (Williams et al., 2007), as indicated by both ecosystem process models and atmospheric inversions solving for surface sources and sinks of $\mathrm{CO}_{2}$. Nearly a quarter of the year-to-year variation in the global-scale exchange of $\mathrm{CO}_{2}$ between land and atmosphere can be attributed to the African continent (Williams et al., 2007).

The major source of this variability is gross primary productivity whose variation exceeds that of ecosystem respiration (Ciais et al., 2009; Weber et al., 2009; Williams et al., 
Table 10. $\mathrm{CH}_{4}$ fluxes from biogenic processes and fires. Total surfaces derived from Globcover.

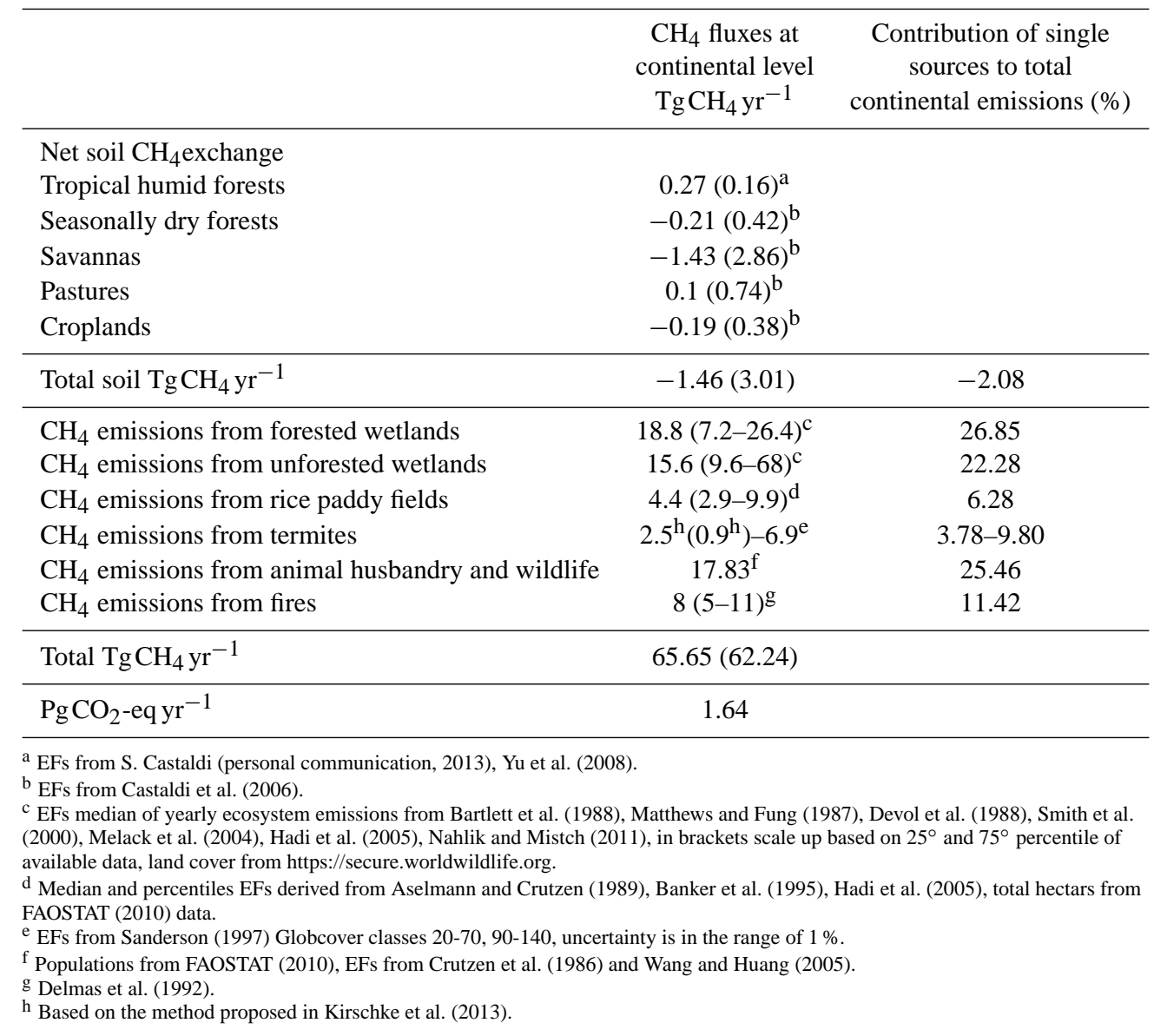

2008). Hydroclimatic fluctuations are the prevailing cause, with much of the continent being water-limited and subject to highly variable precipitation inputs (Weber et al., 2009; Williams et al., 2008). There is wide inconsistency among models regarding the magnitude and spatial allocation of interannual variations in ecosystem productivity (Weber et al., 2009) (e.g. Fig. 6). Models do tend to agree that variability is high in the Sudanian-Sahelian transition zone, equatorial East Africa, and south-central to southeastern Africa. These are regions where hydroclimatic fluctuations are reported to be correlated with El Niño-Southern Oscillation (ENSO) and/or the Indian Ocean Dipole (or Zonal Mode) climate oscillations (Nicholson and Kim, 1997; Reason, 2002; Reason and Rouault, 2002; Richard et al., 2000). Recent work has demonstrated their sizeable effects on carbon exchanges (Ciais et al., 2009; Williams, 2010; Williams and Hanan, 2011) (Fig. 7). While important, we note that such teleconnections explain only a small fraction of continentwide interannual variability in water and carbon balances.

Long-term hydroclimatic trends are another important source of variability at the regional scale, and have been noted as particularly strong in the Sudano-Sahelian zone (e.g. Nicholson, 2000, 2001; Tyson et al., 2002; Nicholson and Kim, 1997). This drives corresponding periods of greening or browning at decadal scales (Prince et al., 2007; Herrmann et al., 2005). Such patterns are also reflected in carbon sinks or sources and can be attributed to increases and decreases in precipitation, but have also been linked to growth enhancement from rising concentrations of carbon dioxide (Ciais et al., 2009) (Fig. 8).

Though Africa contributes a large fraction of global fire emissions, at nearly half of the global total (see Sect. 3.7), the continent's pyrogenic emissions are less interannually variable in both relative and absolute terms compared to other regions of the world, such as southeast Asia and Oceania, as well as South America (van der Werf et al., 2006).

\section{Integrating the African GHG budget}

Table 11 synthesizes the best available estimates of carbon fluxes and pools in Africa, including flux data for methane and nitrous oxide, derived by different approaches (inventory, ecosystem fluxes, models, atmospheric inversions). There are still large uncertainties within (and between) each of the approaches. For each of the different approaches used, 
Table 11. Synthesis of current estimates of GHG and carbon fluxes and pools in Africa. All these values do not include fossil fuel emissions. Reference periods are indicated in the footnotes.

\begin{tabular}{|c|c|c|c|c|}
\hline & $\begin{array}{c}\text { Inventory } \\
\text { data }\end{array}$ & $\begin{array}{l}\text { Ecosystem } \\
\text { fluxes }^{\mathrm{a}}\end{array}$ & $\begin{array}{l}\text { Models } \\
(\text { DGVM })^{\mathrm{b}}\end{array}$ & $\begin{array}{l}\text { Atmospheric } \\
\text { inversions }\end{array}$ \\
\hline \multicolumn{5}{|l|}{ Area (Mha) } \\
\hline Forest & $708 \pm 89^{d}$ & & & \\
\hline Savannas & $769 \pm 109^{d}$ & & & \\
\hline Crops & $477 \pm 14^{\mathrm{d}}$ & & & \\
\hline \multicolumn{5}{|l|}{ Stocks (Pg C) } \\
\hline Forest biomass & $63 \pm 24^{\mathrm{d}}$ & & & \\
\hline \multicolumn{5}{|l|}{ Carbon fluxes $\left(\mathrm{PgC} \mathrm{Cr}^{-1}\right)$} \\
\hline Gross primary production & $31.7 \pm 6.6$ & $24.3 \pm 2.9^{\mathrm{a}}$ & $28.2 \pm 5.9^{\mathrm{b}}$ & \\
\hline Forest & $18.8 \pm 5.3^{\mathrm{e}}$ & & & \\
\hline Savannas & $12.9 \pm 1.9^{\mathrm{e}}$ & & & \\
\hline Net primary production & $14.3 \pm 3.7$ & & $13.3 \pm 3.3^{\mathrm{b}}$ & \\
\hline Forests & $8.5 \pm 2.4^{\mathrm{f}}$ & & & \\
\hline Savannas & $5.8 \pm 2.8^{\mathrm{g}}$ & & & \\
\hline Autothropic respiration & $17.4 \pm 7.6^{\mathrm{h}}$ & & & \\
\hline Forests & $11.1 \pm 6.7^{\mathrm{i}}$ & & & \\
\hline Savannas & $6.3 \pm 10.0$ & & & \\
\hline Heterotrophic respiration & $12.0 \pm 11.3$ & & $12.1 \pm 1.1^{\mathrm{b}}$ & \\
\hline Forests & $7.1 \pm 4.7^{\mathrm{i}}$ & & & \\
\hline Savannas & $4.8 \pm 10.3^{\mathrm{j}}$ & & & \\
\hline Total respiration & $29.3 \pm 13.6$ & $19.0 \pm 1.4^{\mathrm{a}}$ & & \\
\hline Net ecosystem production & $-2.3 \pm 1.2$ & $-2.9 \pm 1.3^{\mathrm{a}}$ & $-1.2 \pm 3.5^{\mathrm{b}}$ & \\
\hline Land-use emissions & $0.51 \pm 0.10$ & & & \\
\hline Deforestation $\left(\mathrm{PgCyr}^{-1}\right)$ & $0.32 \pm 0.05^{\mathrm{k}}$ & & & \\
\hline Forest degradation $\left(\mathrm{PgCyr}^{-1}\right)$ & $0.19 \pm 0.09^{f}$ & & & \\
\hline Wildfires emissions $\left(\mathrm{PgC} \mathrm{yr}^{-1}\right)$ & $1.03 \pm 0.22^{1}$ & & & \\
\hline \multicolumn{5}{|l|}{ Lateral transport $\left(\mathrm{PgCyr}^{-1}\right)$} \\
\hline Carbon in trade & $0.000008^{\mathrm{m}}$ & & & \\
\hline DIC & $0.029^{\mathrm{n}}$ & & & \\
\hline DOC & $0.018^{\mathrm{n}}$ & & & \\
\hline POC & $0.016^{\mathrm{n}}$ & & & \\
\hline Net biome production $\left(\mathrm{PgCyr}^{-1}\right)$ & $-0.74 \pm 1.19$ & $-1.34 \pm 1.32^{\mathrm{a}}$ & $-0.41 \pm 0.31^{\mathrm{b}}$ & $0.05 \pm 0.28^{\mathrm{c}}$ \\
\hline Net biome production $\left(\mathrm{PgCO}_{2} \mathrm{yr}^{-1}\right)$ & $-2.66 \pm 4.28$ & $-4.82 \pm 4.75$ & $-1.48 \pm 1.12$ & $0.18 \pm 1.01$ \\
\hline \multicolumn{5}{|l|}{ Other GHG fluxes } \\
\hline $\mathrm{CH}_{4}$ fluxes $\left(\mathrm{Tg} \mathrm{CH}_{4} \mathrm{yr}^{-1}\right)$ & $65.65 \pm 35^{\circ}$ & & & \\
\hline $\mathrm{CH}_{4}$ fluxes $\left(\mathrm{PgCO}_{2}-\mathrm{eq}\right)$ & $1.64 \pm 0.85^{\circ}$ & & & \\
\hline $\mathrm{N}_{2} \mathrm{O}$ fluxes $\left(\mathrm{TgN}_{2} \mathrm{Oyr}^{-1}\right)$ & $3.3 \pm 1.3^{\circ}$ & & & \\
\hline $\mathrm{N}_{2} \mathrm{O}$ fluxes $\left(\mathrm{PgCO}_{2}\right.$-eq $\left.\mathrm{yr}^{-1}\right)$ & $0.98 \pm 0.41^{\circ}$ & & & \\
\hline Total other GHG fluxes & $2.62 \pm 1.28$ & & & \\
\hline $\mathrm{NMHC}\left(\mathrm{PgCyr}^{-1}\right)$ & $0.16 \pm 0.04^{\mathrm{P}}$ & & & \\
\hline $\mathrm{NMHC}\left(\mathrm{PgCO}_{2} \mathrm{yr}^{-1}\right)$ & $0.59 \pm 0.12$ & & & \\
\hline
\end{tabular}

a Reference period: $1982-2008$.

b Reference period: 1990-2010.

c Reference period: 1996-2004. Inversion systems: Jena_s96, LSC2_var, LSCE_an, and C-tracker_EU.

${ }^{\mathrm{d}}$ Median value and error estimated as 95 and 0.5 percentile.

e Derived by NPP/0.45 error derived by uncertainty in area estimation.

${ }^{\mathrm{f}}$ Estimated by this study.

$\mathrm{g}$ Derived by Bombelli et al.(2009) and Lehsten et al. (2009).

h Derived by GPP-NPP.

${ }^{i}$ Derived by Malhi et al. (2009).

j Derived by Gilmanov et al. (2010).

k Reference period: 1990-2009.

${ }^{1}$ Reference period: 1997-2011.

$\mathrm{m}$ Derived by Davis et al. (2011)

${ }^{\mathrm{n}}$ Reference period: $1980-2000$.

o The time period of input data was centered on 2000, based on availability of most input data, which spanned from the middle of 1990 s to

2009.

p Derived by Kesselmeier et al. (2002). 
SiB3

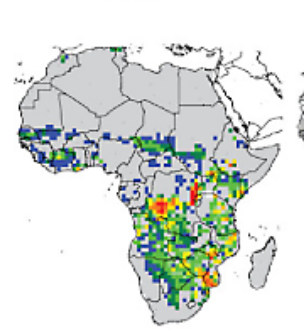

LPJ-DGVM

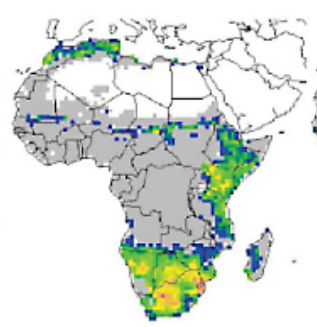

ORCHIDEE

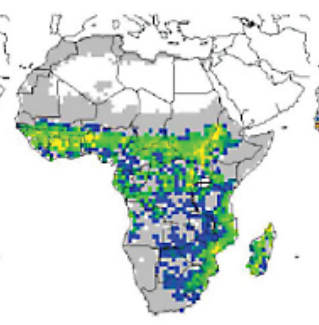

JULES

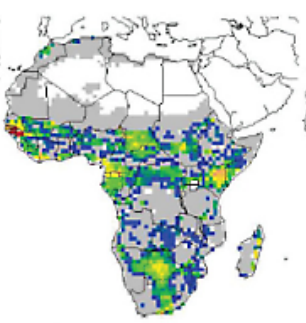

LPJ-GUESS

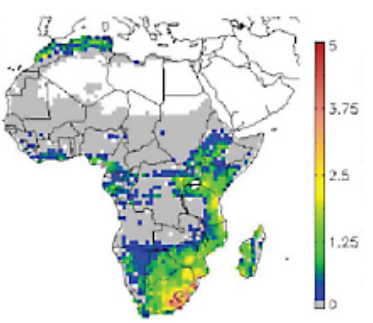

Fig. 6. Standardized interannual variability of gross primary productivity, defined according to Weber et al. (2009) as $\frac{\mathrm{IAV}}{\sigma_{\mathrm{IAV}}} \overline{\mathrm{IAV}}$, from five modeling exercises. SiB3 results were reported in Williams et al. (2008) and cover the period 1982-2003 and the remaining four were reported in Weber et al. (2009) spanning 1982-2008, reproduced with permission. Values greater than 0 indicate above average interannual variability.
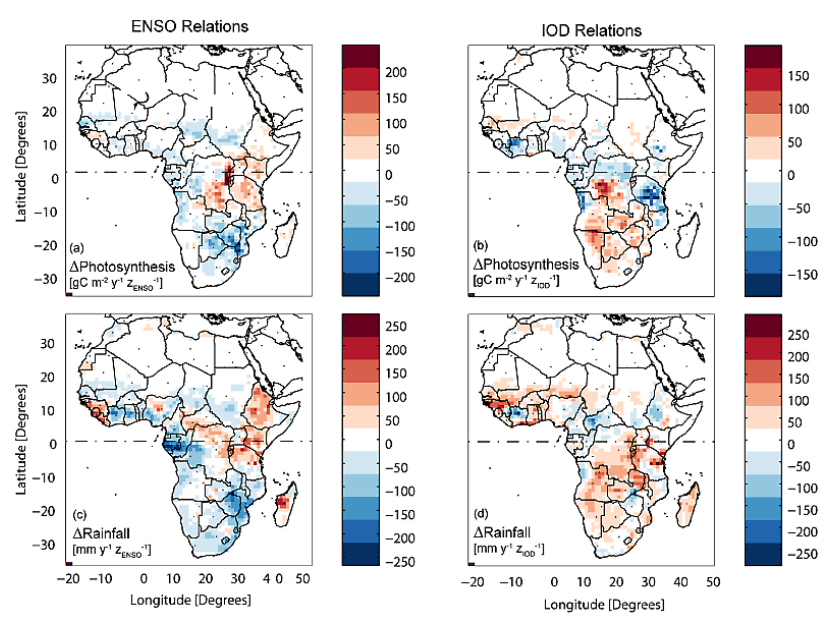

Fig. 7. Spatial distribution across Africa of the slope of least-squares linear regressions of SiB3 modeled $(\mathbf{a}, \mathbf{b})$ annual net photosynthesis $\left(P_{\text {net }}\right)$ or CRU/TRMM $(\mathbf{c}, \mathbf{d})$ annual rainfall on climate indices. Each column corresponds to analyses with a particular index with the left column $(\mathbf{a}, \mathbf{c})$ for the multivariate ENSO index, and the right column (b, d) for the Indian Ocean Dipole Mode Index (IOD). Results are based on Williams et al. (2008).

we have calculated, on the basis of the best available data, the net carbon balance as follows: NEP - Fires - Land use - lateral transport (DOC only). From these results, we can conclude that the contribution by the African continent to the global carbon cycle ranges between a slight source of $0.05 \pm$ $0.28 \mathrm{Pg} \mathrm{Cyr}^{-1}$ (estimated by the atmospheric inversion, excluding fossil fuel) to a sink of $-1.34 \pm 1.32 \mathrm{Pg} \mathrm{C} \mathrm{yr}^{-1}$ (estimated by the ecosystem fluxes). The median estimate is

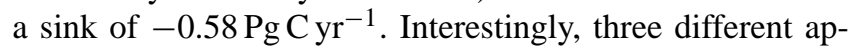
proaches provide quite similar GPP fluxes $(31.7 \pm 6.6,24.3 \pm$ 2.9, 28.2 $\pm 5.9 \mathrm{Pg} \mathrm{C} \mathrm{yr}^{-1}$ for inventory data, ecosystem fluxes and DGVM model, respectively). NPP also seems to be well constrained by both inventory and DGVM estimates $\left(14.3 \pm 3.7\right.$ and $13.3 \pm 3.3 \mathrm{Pg} \mathrm{Cyr}^{-1}$, respectively). Thus, the inconsistencies between the approaches reside in the respi- ration fluxes (broadly defined, to include domestic and wild fire and decomposition of soil, biomass and litter stocks following land cover change).

Although total GPP and NPP seems to be reasonably constrained, respiratory fluxes show high uncertainties and reflect the difficulty of both measurements and a modeling approach. In particular, the assumptions to derive respiratory fluxes by inventory are weak. This is partly due to the paucity of data and in situ measurements able to represent the full range of African ecosystems. The similar estimates for heterotrophic respiration derived from inventory and DGVMs is likely to be coincidental.

The comparison of inventories, ecosystem flux measurements, and DGVM estimates of NEE with atmospheric inversions can only be carried out by correctly accounting for the lateral transport of carbon and for the land-use change emissions. For this reason, we have compiled relevant data on land-use emissions and lateral transport (see Sects. 3.6 and 3.8, respectively) as common input data for all the approaches. While all the approaches based on inventories, ecosystem fluxes, and models indicate a modest carbon sink $\left(-0.74 \pm 1.19,1.34 \pm 1.32,-0.41 \pm 0.31 \mathrm{Pg} \mathrm{C} \mathrm{yr}^{-1}\right.$, respectively), the atmospheric inversions, excluding fossil fuel, show a small carbon source $\left(0.05 \pm 0.28 \mathrm{PgC} \mathrm{yr}^{-1}\right)$. There are several reasons for such discrepancies, mostly related to the features of the individual approaches and their assumptions. The discrepancies are within the uncertainty associated with the various approaches. In the case of inventory, the reconstruction of carbon fluxes from NPP is based on a few data sets from savannas and some speculative exercises for tropical forests. Flux data and their spatial integration in Africa suffer from the low number of field sites and the lack of adequate representation of all ecosystem types. The likely effects of terrain and night-time fluxes on the estimation of the overall annual budget (and in particular the respiration fluxes) are severe. In this paper, the possibility of some overestimation of net ecosystem exchanges from flux data is also considered. DGVM may not adequately represent plant functional types in Africa and respiratory fluxes. Furthermore, 

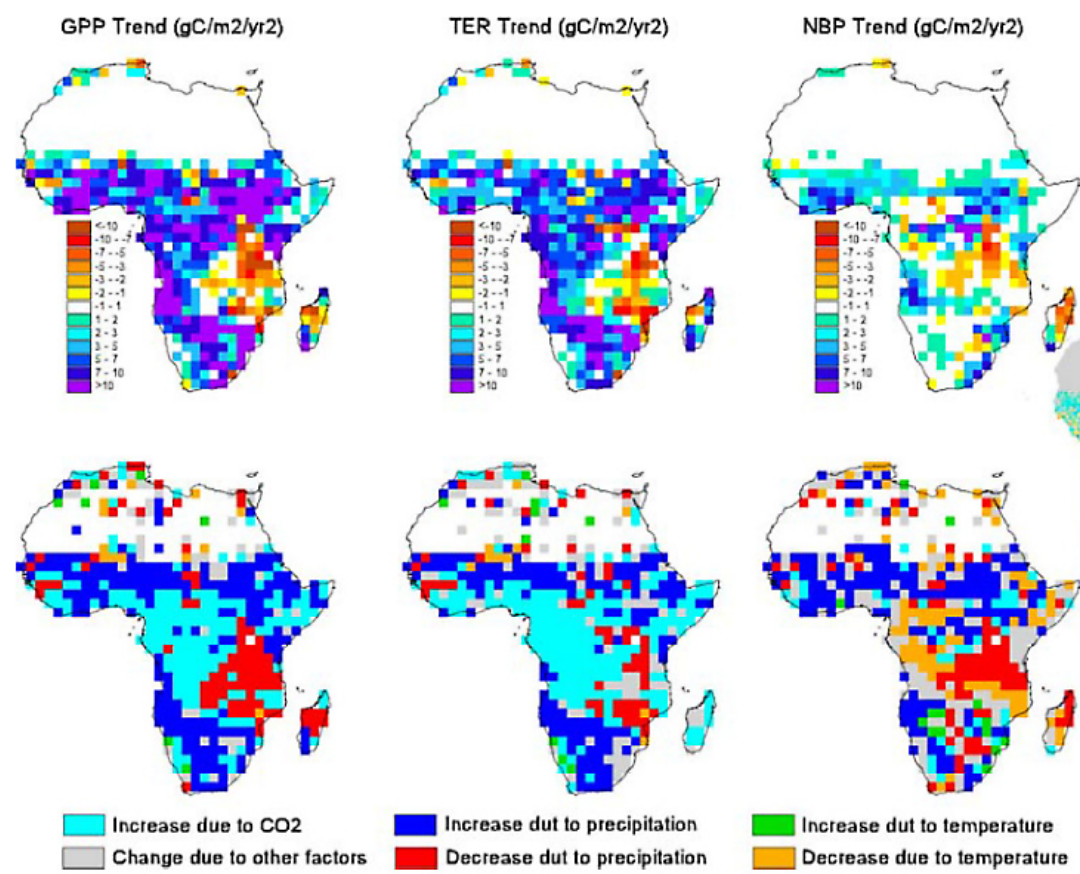

NDVI Trend ("1000)
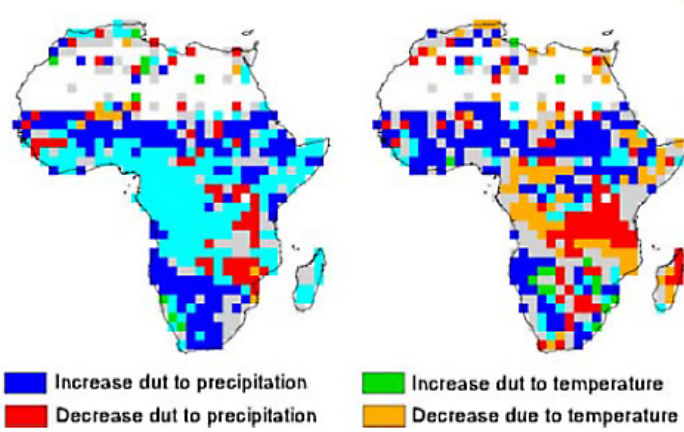

Fig. 8. Spatial distributions of ORCHIDEE modeled trends in annual GPP, TER, and NBP from 1980 to 2002 and of their main driving factor. Reproduced with permission from Ciais et al. (2009).

the emissions by unsustainable land use, mainly fuel wood extraction leading to forest degradation may be underestimated. Atmospheric inversions are affected by the lack of a reasonable network of observation sites in Africa. In addition, interannual variability plays an important role and the overall carbon balance may easily swing from a sink to a source of carbon following climate variability and anthropogenic changes.

The contribution of $\mathrm{N}_{2} \mathrm{O}$ and $\mathrm{CH}_{4}$ fluxes to the overall GHG balance of the African continent is equivalent to $2.62 \pm 1.28 \mathrm{PgCO}_{2}$-eq $\mathrm{yr}^{-1}$. $\mathrm{CH}_{4}$ is the dominant emission $\left(1.64 \pm 0.85 \mathrm{PgCO}_{2}\right.$-eq yr $\left.{ }^{-1}\right)$ while $\mathrm{N}_{2} \mathrm{O}$ is $0.98 \pm$ $0.41 \mathrm{Pg} \mathrm{CO}_{2}$-eq $\mathrm{yr}^{-1}$. If we compare these estimates with the carbon balance of the continent, we can say that the role of non- $\mathrm{CO}_{2}$ gases emissions is prevalent in making the continent a net source of greenhouse gases.

\section{Key uncertainties and research gaps}

After having assessed the availability of data, the key processes involved in the GHG balance of Africa, and the suitability of the various methods that have been used, some conclusions can be drawn as the following:

1. There is a general lack of data and information on relevant processes at ecosystem level, able to constrain atmospheric data and DGVM models. This includes respiratory fluxes and NPP data, particularly for tropi- cal rainforest, and for several other ecosystems such as savannas and the woodlands transitional to forests.

2. Although land-use emissions are increasingly well studied, there still are gaps relating to forest degradation and other land use that make the African continent unique, such as selective logging, biomass use for charcoal production, and the effects of shifting agriculture.

3. Interannual variability is the major feature of the continental carbon fluxes, believed to be of the order of $\pm 0.5 \mathrm{Pg} \mathrm{C} \mathrm{yr}^{-1}$ in standard deviation accounting for as much as a quarter of the year-to-year variation in the global carbon budget.

4. It seems that climatic fluctuations (particularly as they impact the water balance), are an important source of variability at the regional scale, and have been noted as particularly strong in the Sudano-Sahelian zone. Integrating the biogeochemical cycles of carbon and water research is therefore of particular importance in understanding the dynamics of the African carbon balance.

5. Non- $\mathrm{CO}_{2}$ greenhouse gas emissions are poorly studied across the various African ecosystems. In particular, little is known about how they are affected by land use and climate. The lack of such information hinders the understanding of the African methane budget at global level and provision of an insight on the natural sources of nitrous oxide. 
6. Since both climate and human pressures will play an important role on the future of the African region, a greater effort on in situ and atmospheric observations is urgently needed and should also comprise of socio-economic drivers of change. Integrated interdisciplinary research would allow us to reduce uncertainties in the carbon and other GHG fluxes of the continent and to understand its temporal and spatial variability in response to climate and land-use drivers.

The vast majority of the results from this study and the literature, based on different methodologies and for different time periods (see Table 11), seem to agree that Africa is probably a small sink of carbon on an annual timescale. By averaging out all the estimates, this value is $-0.61 \pm 0.58 \mathrm{Pg} \mathrm{Cyr}^{-1}$. Nevertheless, the emissions of $\mathrm{CH}_{4}$ and $\mathrm{N}_{2} \mathrm{O}$ may turn Africa into a carbon source.

At sub-regional level, there is a significant spatial variability in both carbon sources and sinks, mainly due to the biome's change and the different anthropic impact, with southern Africa as the main source and central Africa as the main sink. In particular, $33 \%$ of the global tropical forest carbon sink (and $16 \%$ of the global terrestrial carbon sink) is estimated to be due to African tropical forests that contain around $78 \mathrm{Pg}$ of above ground biomass.

Emissions from land-use change in Africa are significant (around $0.32 \pm 0.05 \mathrm{Pg} \mathrm{C} \mathrm{yr}^{-1}$ ) and even higher than the fossil fuel ones; this is a unique feature among all the continents. In addition, there can be significant carbon losses from land even without changes in the land use (forest), resulting from the impact of selective logging.

Fires also play a significant role, with around $1.03 \pm$ $0.22 \mathrm{Pg} \mathrm{Cyr}^{-1}$ of annual carbon emissions mainly $(90 \%)$ originating from savanna and woodland burning. On a global scale, this contributes to more than half $(52 \%)$ of the global carbon emissions by fires, and more than a third (36\%) of $\mathrm{CH}_{4}$ emissions.

The African continent is responsible for a large fraction (around $25 \%$ ) of the global carbon cycle's interannual variability.

These figures as a whole, even if still highly uncertain, show the important role Africa plays in the carbon cycle at a global level, both in terms of absolute values and variability.

Acknowledgements. The research leading to these results has received funding from the European Research Council (ERC) under grant agreement no. 247349 "Africa-GHG".

We would like also to thank Christian Roedenbeck and Wouter Peters for having provided the results of two atmospheric inversions (JENA and CarbonTracker Europe systems) that were further processed and made available through the CarboScope website like the other inversions (http://www.carboscope.eu). We also thank the ecosystem modeling groups that participated in the Trendy inter comparison project, for having made available their simulations.

\section{References}

Alam, S. A., Starr, M., and Clark, B. J. F.: Tree Biomass and Soil Organic Carbon Densities Across the Sudanese Woodland Savannah: A Regional Carbon Sequestration Study, J. Arid Environ., 89, 67-76, 2013.

Archibald, S., Nickless, A., Govender, N., Scholes, R. J., and Lehsten, V.: Climate and the Inter-Annual Variability o Fire in Southern Africa: A Meta-Analysis Using Long-Term Field Data and Satellite-Derived Burnt Area Data, Global Ecol. Biogeogr., 19, 794-809, 2010.

Archibald, S., Staver, A. C., and Levin, S. A.: Evolution of HumanDriven Fire Regimes in Africa, P. Natl. Acad. Sci. USA, 109, 847-852, 2011.

Arneth, A., Lehsten, V., Thonicke, K., and Spessa, A.: ClimateFire Interactions and Savanna Ecosystems: A Dynamic Vegetation Modelling Study For The African Continent, In: Ecosystem Function in Savannas: Measurement and Modeling at Landscape to Global Scales, edited by: Hill, M. J. and Hanan, N. P., Taylor \& Francis/CRC, Boca Raton, 463-478, 2010a.

Arneth, A., Sitch, S., Bondeau, A., Butterbach-Bahl, K., Foster, P., Gedney, N., de Noblet-Ducoudré, N., Prentice, I. C., Sanderson, M., Thonicke, K., Wania, R., and Zaehle, S.: From Biota to Chemistry and Climate: Towards a Comprehensive Description of Trace Gas Exchange Between the Biosphere and Atmosphere, Biogeosciences, 7, 121-149, doi:10.5194/bg-7-1212010, 2010b.

Aselmann, I. and Crutzen, P. J.: Global Distribution of Natural Freshwater Wetlands and Rice Paddies, and Their Net Primary Productivity, Seasonality and Possible Methane Emissions, J. Atmos. Chem., 8, 307-358, 1989.

Baccini, A., Laporte, N., Goetz, S. J., Sun, M., and Dong, H.: A First Map of Tropical Africa's Above-Ground Biomass Derived From Satellite Imagery, Environ. Res. Lett., 3, 045011, doi:10.1088/1748-9326/3/4/045011, 2008.

Baccini, A., Goetz, S. J., Walker, W. S., Laporte, N. T., Sun, M., Sulla-Menashe, D., Hackler, J., Beck, P. S. A., Dubayah, R. Friedl, M. A., Samanta, S., and Houghton, R. A.: Estimated Carbon Dioxide Emissions from Tropical Deforestation Improved by Carbon-Density Maps, Nat. Clim. Change, 2, 182-185, 2012.

Banker, B. C., Hludze, H. K., Alford, D. P., DeLaune, R. D., and Lindau, C. W.: Methane Sources and Sinks in Rice Paddy Soils: Relationship to Emissions, Agriculture, Ecosyst. Environ., 53, 243-251, 1995.

Bartlett, K. B., Crill, P. M., Sebacher, D. I., Harriss, R. C., Wilson, J. O., and Melack, J. M.: Methane Flux From the Central Amazonian Floodplain, J. Geophys. Res., 93, 1571-1582, 1988.

Bombelli, A., Henry, M., Castaldi, S., Adu-Bredu, S., Arneth, A., de Grandcourt, A., Grieco, E., Kutsch, W. L., Lehsten, V., Rasile, A., Reichstein, M., Tansey, K., Weber, U., and Valentini, R.: An Outlook on the Sub-Saharan Africa Carbon Balance, Biogeosciences, 6, 2193-2205, doi:10.5194/bg-6-2193-2009, 2009.

Bonan, G. B. and Levis, S.: Quantifying Carbon-Nitrogen Feedbacks in the Community Land Model (CLM4), Geophys. Res. Lett., 37, L07401, doi:10.1029/2010GL042430, 2010.

Bond, W. J., Woodward, F. I., and Midgley, G. F.: The Global Distribution of Ecosystems in a World Without Fire, New Phytol., 165, 525-538, 2005.

Edited by: J. Canadell 
Bouwman, A. F., Boumans, L. J. M., and Batjes, N. H.: Modeling Global Annual $\mathrm{N}_{2} \mathrm{O}$ and $\mathrm{NO}$ Emissions From Fertilized Fields, Global Biogeochem. Cy., 16, 1080-1090, 2002.

Brown, S. and Gaston, G: Use of Forest Inventories and Geographic Information Systems to Estimate Biomass Density of Tropical Forests: Application to Tropical Africa, Environ. Monitor. Assess., 38, 157-168, 1995.

Bousquet, P., Ciais, P., Peylin, P., Ramonet, M., and Monfray, P.: Inverse Modeling of Annual Atmospheric $\mathrm{CO}_{2}$ Sources and Sinks 1. Method and Control Inversion, J. Geophys. Res.-Atmos., 104, 26161-26178, 1999.

Canadell, J. G., Raupach, M. R., and Houghton, R. A.: Anthropogenic $\mathrm{CO}_{2}$ Emissions in Africa, Biogeosciences, 6, 463-468, doi:10.5194/bg-6-463-2009, 2009a.

Canadell, J. G., Ciais, P., Dhakal, S., Le Quéré, C., Patwardhan, A., and Raupach, M. R.: The Human Perturbation of the Carbon Cycle, UNESCO-UNEP-SCOPE Policy Brief, Paris, 6 pp., $2009 \mathrm{~b}$.

Canadell, J. G., Ciais, P., Gurney, K., Le Quéré, C., Piao, S., Raupach, M. R., and Sabine, C. L.: An International Effort to Quantify Regional Carbon Fluxes, EOS Trans. AGU, 92, 81-82, 2011.

Castaldi, S., Ermice, A., and Strumia, S.: Fluxes of $\mathrm{N}_{2} \mathrm{O}$ and $\mathrm{CH}_{4}$ from Soils of Savannas and Seasonally-Dry Ecosystems, J. Biogeogr., 33, 401-415, 2006.

Castaldi, S., de Grandcourt, A., Rasile, A., Skiba, U., and Valentini, R.: $\mathrm{CO}_{2}, \mathrm{CH}_{4}$ and $\mathrm{N}_{2} \mathrm{O}$ fluxes from soil of a burned grassland in Central Africa, Biogeosciences, 7, 3459-3471, doi:10.5194/bg7-3459-2010, 2010.

Castaldi, S., Bertolini, T., Valente, A., Chiti, T., and Valentini, R.: Nitrous Oxide Emissions from Soil of an African Rain Forest in Ghana, Biogeosciences, 10, 4179-4187, doi:10.5194/bg-104179-201, 2013.

Cazzolla Gatti, R., Castaldi, S., Lindsell, J. A., Coomes, D. A., Marchetti, M., Maesano, M., Di Paola, A., Paparella, F., and Valentini, R.: The Impact of Selective Logging on Forest Structure, Tree Diversity and Above-Ground Biomass of African Tropical Forests, Forest Ecol. Manag., in review, 2014.

Chevallier, F., Maksyutov, S., Bousquet, P., Bréon, F.-M., Saito, R., Yoshida, Y., and Yokota, T.: On the Accuracy of the $\mathrm{CO}_{2}$ Surface Fluxes to be Estimated From the GOSAT Observations, Geophys. Res. Lett., 36, L19807, doi:10.1029/2009GL040108, 2009.

Chevallier, F., Ciais, P., Conway, T. J., Aalto, T., Anderson, B. E., Bousquet, P., Brunke, E. G., Ciattaglia, L., Esaki, Y., Fröhlich, M., Gomez, A., Gomez-Pelaez, A. J., Haszpra, L., Krummel, P., Langenfelds, R., Leuenberger, M., Machida, T., Maignan, F., Matsueda, H., Morgu, J. A., Mukai, H., Nakazawa, T., Peylin, P., Ramonet, M., Rivier, L., Sawa, Y., Schmidt, M., Steele, P., Vay, S. A., Vermeulen, A. T., Wofsy, S., and Worthy, D.: $\mathrm{CO}_{2}$ Surface Fluxes at Grid Point Scale Estimated From a Global 21 Yr Reanalysis of Atmospheric Measurements, J. Geophys. Res., 115, D21307, doi:10.1029/2010JD013887, 2010.

Ciais, P., Piao, S.-L., Cadule, P., Friedlingstein, P., and Chédin, A.: Variability and Recent Trends in the African Terrestrial Carbon Balance, Biogeosciences, 6, 1935-1948, doi:10.5194/bg-61935-2009, 2009.

Ciais, P., Bombelli, A., Williams, M., Piao, S. L., Chave, J., Ryan, C. M., Henry, M., Brender, P., and Valentini, R.: The Carbon Balance of Africa: Synthesis of Recent Research Studies, Philos. T. R. Soc. A, 269, 2038-2057, 2011.
Collatz, G. J., Ball, J. T., Grivet, C., and Berry, J. A.: Physiological and Environmental Regulation of Stomatal Conductance, Photosynthesis and Transpiration: A Model that Includes a Laminar Boundary Layer, Agr. Forest Meteorol., 54, 107-136, 1991.

Collatz, G. J., Ribascarbo, M., and Berry. J. A.: Coupled Photosynthesis-Stomatal Conductcance Model for Leaves $\mathrm{Of} \mathrm{C}_{4}$ Plants, Aust. J. Plant Physiol., 19, 519-538, 1992.

Cox, P. M.: Description of the "TRIFFID" Dynamic Global Vegetation Model, Hadley Centre Technical Note 24, Hadley Centre, Met Office, London Road, Bracknell, Berks, RG122SY, UK, 17 pp., 2001.

Cramer, W., Kicklighter, D. W., Bondeau, A., Moore III, B., Churkina, G., Nemry, B., Ruimy, A., Schloss, A. L., and the participants of the Postdam NPP Model Intercomparison: Comparing Global Models of Terrestrial Net Primary Productivity (NPP): Overview and Key Results, Glob. Change Biol., 5, 1-15, 1999.

Crutzen, P. J., Aselman, I., and Seiler, W.: Methane Production by Domestic Animals, Wild Ruminants, Other Herbivorus Fauna, and Humans, Tellus B, 38, 271-284, 1986.

Davidson, E. A.: Soil Water Content and The Ratio of Nitrous To Nitric Oxide Emitted From Soil, in: Biogeochemistry of Global Change: Radiatively Active Trace Gases, edited by: Oremland, R. S., Chapman \& Hall, London, 369-386, 1993.

Davis, S. J., Peters, G. P., and Caldeira, K.: The Supply Chain of $\mathrm{CO}_{2}$ Emissions, P. Natl. Acad. Sci. USA, 108, 18554-18559, doi:10.1073/pnas.1107409108, 2011.

Deckker, M. and de Graaf, N. R.: Pioneer and Climax Tree Regeneration Following Selective Logging With Silviculture in Suriname, Forest Ecol. Manag., 172, 183-190, 2003.

Delmas, R. A., Tathy, J. P., and Cross, B.: Atmospheric Methane Budget in Africa, J. Atmos. Chem., 14, 395-409, 1992.

Dentener, F., Drevet, J., Lamarque, J. F., Bey, I., Eickhout, B., Fiore, A. M., Hauglustaine, D., Horowitz, L. W., Krol, M., Kulshrestha, U. C., Lawrence, M., Galy-Lacaux, C., Rast, S., Shindell, D., Stevenson, D., Van Noije, T., Atherton, C., Bell, N., Bergman, D., Butler, T., Cofala, J., Collins, B., Doherty, R., Ellingsen, K., Galloway, J., Gauss, M., Montanaro, V., Müller, J. F., Pitari, G., Rodriguez, J., Sanderson, M., Solmon, F., Strahan, S., Schultz, M., Sudo, K., Szopa, S., and Wild, O.: Nitrogen and Sulfur Deposition on Regional and Global Scales: A Multimodel Evaluation, Global Biogeochem. Cy., 20, GB4003, doi:10.1029/2005GB002672, 2006.

Devol, A. H., Richey, J. E., Clark, W. A., and King, S. L.: Methane Emissions to the Troposphere from the Amazon Floodplain, J. Geophys. Res., 93, 1583-1592, 1988.

Ellicott, E., Vermote, E., Giglio, L., and Roberts, G.: Estimating Biomass Consumed From Fire Using MODIS FRE, Geophys. Res. Lett., 36, L13401, doi:10.1029/2009GL038581, 2009.

FAO: Global Forest Resources Assessment 2005, Main Report, Progress Towards Sustainable Forest Management, FAO Forestry Paper 147, Food and Agriculture Organization of the United Nations, Rome, Italy, 320 pp., 2006.

FAO: Global Forest Resources Assessment 2010, FAO Forestry Paper 163, Food and Agriculture Organization of the United Nations, Rome, 340 pp., available at: http://www.fao.org/forestry/ fra/fra2010/en/, 2010.

FAOSTAT: available at: http://faostat.fao.org/site/377/default.aspx\# ancor (last access: November 2009), 2009. 
Farquhar, G. D., von Caemmerer, S., and Berry, J. A.: A Biochemical Model of Photosynthetic $\mathrm{CO}_{2}$ Assimilation in Leaves of $\mathrm{C}_{3}$ Species, Planta, 149, 78-90, 1980.

Fekete, B. M., Vöröosmarty, C. J., and Grabs W.: High-Resolution Fields of Global Runoff Combining Observed River Discharge and Simulated Water Balances, Global Biogeochem. Cy., 16, 151-15-10, doi:10.1029/1999GB001254, 2002.

Friedlingstein, P., Houghton, R. A., Marland, G., Hackler, J., Boden, T. A., Conway, T. J., Canadell, J. G., Raupach, M. R., Ciais, P., and Le Quéré, C.: Update on $\mathrm{CO}_{2}$ Emissions, Nat. Geosci., 3, 811-812, 2010.

Gibbs, H. K., Ruesch, A. S., Achard, F., Clayton, M. K., Holmgren, P., Ramankutty, N., and Foley, J. A.: Tropical Forests Were the Primary Sources of New Agricultural Land in The 1980s and 1990s, P. Natl. Acad. Sci. USA, 107, 16732-16737, 2010.

Giglio, L., Loboda, T., Roy, D. P., Quayle, B., and Justice, C. O.: An Active-Fire Based Burned Area Mapping Algorithm for the MODIS Sensor, Remote Sens. Environ., 113, 408-420, 2009.

Giglio, L., Randerson, J. T., van der Werf, G. R., Kasibhatla, P. S., Collatz, G. J., Morton, D. C., and DeFries, R. S.: Assessing Variability and Long-Term Trends in Burned Area by Merging Multiple Satellite Fire Products, Biogeosciences, 7, 1171-1186, doi:10.5194/bg-7-1171-2010, 2010.

Gilmanov, T. G., Aires, L., Belelli, L., Barcza, Z., Baron, V. S., Beringer, J., Billesbach, D., Bonal, D., Bradford, J., Ceschia, E., Cook, D., Corradi, C., Frank, A., Gianelle, D., Gimeno, C., Gruenwald, T., Guo, H., Hanan, N., Haszpra, L., Heilman, J., Jacobs, A., Jones, M. B., Johnson, D. A., Kiely, G., Li, S., Magliulo, V., Moors, E., Nagy, Z., Nasyrov, M., Owensby, C., Pinter, K., Pio, C., Reichstein, M., Sanz, M. J., Scott, R., Soussana, J. F., Stoy, P. C., Svejcar, T., Tuba, Z., and Zhou, G.: Productivity, Respiration, and Light-Response Parameters of World Grassland and Agro-Ecosystems Derived from Flux-Tower Measurements, Rangeland Ecol. Manag., 63, 16-39, doi:10.2111/REMD-09-00072.1, 2010.

Glenday, J.: Carbon Storage and Emissions Offset Potential in an African Dry Forest, the Arabuklo-Sokoke Forest, Kenya, Environ. Monit. Assess., 142, 85-95, 2008.

Grace, J., San Jose, J., Meir, P., Miranda, H. S., and Montes, R. A.: Productivity and Carbon Fluxes of Tropical Savannas, J. Biogeogr., 33, 387-400, 2006.

Grieco, E., Chiti, T., Perugini, L., and Valentini, R.: Deforestation and Land Use Change in Jomoro District, Ghana, Impacts on Carbon Stocks and Perspectives of REDD+, in preparation, 2014.

Gurney, K. R., Law, R. M., Denning, A. S., Rayner, P. J., Baker, D., Bousquet, P., Bruhwiler, L., Chen, Y.-H., Ciais, P., Fan, S., Fung, I. Y., Gloor, M., Heimann, M., Higuchi, K., John. J., Maki, T., Maksyutov, S., Masarie, K., Peylin, P., Prather, M., Pak, B. C., Randerson, J., Sarmiento, J., Taguchi, S., Takahashi, T., and Yuen, C.-W.: Towards Robust Regional Estimates of $\mathrm{CO}_{2}$ Sources and Sinks Using Atmospheric Transport Models, Nature, 415, 626-630, 2002.

Gurney, K. R., Law, R. M., Denning, A. S., Rayner, P. J., Pak, B. C., Baker, D., Bousquet, P., Bruhwiler, L., Chen, Y- H., Ciais, P., Fung, I. Y., Heimann, M., John, J., Maki, T., Maksyutov, S., Peylin, P., Prather, M., and Taguchi, S.: Transcom $3 \mathrm{CO}_{2}$ Inversion Intercomparison: 1. Annual Mean Control Results and Sensitivity to Transport and Prior Flux Information, Tellus B, 55, 555-579, 2003.
Hadi, A., Inubushi, K., Furukawa, Y., Purnomo, E., Rasmadi, M., and Tsuruta, H.: Greenhouse Gas Emissions from Tropical Peatlands of Kalimantan, Indonesia, Nutr. Cycl. Agroecosys., 71, 73$80,2005$.

Hartmann, J., Jansen, N., Durr, H. H., Kempe, S., and Kohler, P.: Global $\mathrm{CO}_{2}$ Consumption by Chemical Weathering: What is the Contribution of Highly Active Weathering Regions?, Global Planet. Change, 69, 185-194, 2009.

Hartmann, J., and Moosdorf, N.: Chemical Weathering Rates of Silicate-Dominated Lithological Classes and Associated Liberation Rates of Phosphorus on the Japanese Archipelago - Implications for Global Scale Analysis, Chem. Geol., 287, 125-157, doi:10.1016/j.chemgeo.2010.12.004, 2011.

Henry, M.: Carbon Stocks and Dynamics in Sub Saharan Africa, Ph.D. thesis, University of Tuscia, 2010.

Herrmann, S. M., Anyamba, A., and Tucker, C. J.: Recent Trends in Vegetation Dynamics in the African Sahel and their Relationship to Climate, Global Environ. Chang., 15, 394-404, 2005.

Hickler, T., Smith, B., Prentice, I. C., Mjöfors, K., Miller, P., Arneth, A., and Sykes, M.: $\mathrm{CO}_{2}$ Fertilization in Temperate FACE Experiments Not Representative of Boreal and Tropical Forests, Glob. Change Biol., 14, 1-12, 2008.

Hickman, J. E., Havlikova, M., Kroeze, C., and Palm, C. A.: Current and Future Nitrous Oxide Emissions from African Agriculture, Curr. Opin. Environ. Sust., 3, 370-378, 2011.

Houghton, R. A. and Hackler, J. L.: Emissions of Carbon from Land Use Change in Sub-Saharan Africa, J. Geophys. Res., 111, G02003, doi:10.1029/2005JG000076, 2006.

IFAD: Rural Poverty Report 2001 - The Challenge of Ending Rural Poverty, International Fund for Agricultural Development, Rome, 266 pp., 2001.

IPCC: Revised 1996 IPCC Guidelines for National Greenhouse Gas Inventories, edited by: Houghton, J. T., Meira Filho, L. G., Lim, B., Tranton, K., Mamaty, I., Bonduki, Y., Griggs, D. J., and Callander B. A., Intergovernmental Panel on Climate Change, Meteorological Office, Bracknell, United Kingdom, Vol. 3: Greenhouse Gas Inventory Reference Manual, 482 pp., 1997.

IPCC: Changes in Atmospheric Constituents and Radiative Forcing, edited by: Solomon, S., Qin, D., Manning, M., Chen, Z., Marquis, M., Averyt, K. B., Tignor, M., and Miller, H. L., Climate Change 2007: The Physical Science Basis, Contribution of Working Group I to the Fourth Assessment, Cambridge University Press, Cambridge, UK and New York, NY, USA, 129-234, 2007a.

IPCC: AR4 WGII, Inter-Relationships Between Adaptation and Mitigation, Chapter 18, $2007 \mathrm{~b}$.

Jung, M., Reichstein, M., and Bondeau, A.: Towards Global Empirical Upscaling of FLUXNET Eddy Covariance Observations: Validation of a Model Tree Ensemble Approach Using a Biosphere Model, Biogeosciences, 6, 2001-2013, doi:10.5194/bg6-2001-2009, 2009.

Jung, M., Reichstein, M., Margolis, H., Cescatti, A., Richardson, A., Arain, A., Arneth, A., Bernhofer, C., Bonal, D., Chen, J., Gianelle, D., Gobron, N., Kiely, G., Kutsch, W., Lasslop, G., Law, B., Lindroth, A., Merbold, L., Montagnani, L., Moors, E., Papale, D., Sottocornola, M., Vaccari, F. P., and Williams, C.: Global Patterns of Land-Atmosphere Fluxes of Carbon Dioxide, Latent Heat, and Sensible Heat Derived from Eddy Covariance, Satel- 
lite, and Meteorological Observations, J. Geophys. Res., 116, G00J07, doi:10.1029/2010JG001566, 2011.

Keller, M., Veldkamp, E., Weitz, A. M., and Reiners, W. A.: Effect of Pasture Age on Soil Trace-Gas Emissions from a Deforested Area of Costa Rica, Nature, 365, 244-246, 1993.

Kesselmeier, J., Ciccioli, P., Kuhn, U., Stefani, P., Biesenthal, T., Rottenberger, S., Wolf, A., Vitullo, M., Valentini, R., Nobre, A., Kabat, P., and Andreae, M. O.: Volatile Organic Compound Emissions in Relation to Plant Carbon Fixation and the Terrestrial Carbon Budget, Global Biogeochem. Cy., 16, 1126, doi:10.1029/2001GB001813, 2002.

Kirschke, S., Bousquet, P., Ciais, P., Saunois, M., Canadell, J. G., Dlugokencky, E. J., Bergamaschi, P., Bergmann, D., Blake, D. R., Bruhwiler, L., Cameron-Smith, P., Castaldi, S., Chevallier, F., Feng, L., Fraser, A., Fraser, P. J., Heimann, M., Hodson, E. L., Houweling, S., Josse, B., Krummel, P. B., Lamarque, J., Langenfelds, R. L., Le Quéré, C., Naik, V., O’Doherty, S., Palmer, P. I., Pison, I., Plummer, D., Poulter, B., Prinn, R. G., Rigby, M., Ringeval, B., Santini, M., Schmidt, M., Shindell, D. T., Simpson, I. J., Spahni, R., Steele, L. P., Strode, S. A., Sudo, K., Szopa, S., van der Werf, G. R., Voulgarakis, A., van Weele, M., Weiss, R. F., Williams, J. E., and Zeng, G.: Three Decades of Methane Sources and Sinks: Budgets and Variations, Nat. Geosci., 6, 813823, doi:10.1038/ngeo1955, 2013.

Krinner, G., Viovy, N., de Noblet-Ducoudré, N., Ogée, J., Polcher, J., Friedlingstein, P., Ciais, P., Sitch, S., and Prentice, I. C.: A Dynamic Global Vegetation Model for Studies of the Coupled Atmosphere-Biosphere System, Global Biogeochem. Cy., 19, GB1015, doi:10.1029/2003GB002199, 2005.

Kutsch, W. L., Hanan, N., Scholes, B., McHugh, I., Kubheka, W., Eckhardt, H., and Williams, C.: Response of Carbon Fluxes to Water Relations in a Savanna Ecosystem in South Africa, Biogeosciences, 5, 1797-1808, doi:10.5194/bg-5-1797-2008, 2008.

Kutsch, W. L., Merbold, L., Ziegler, W., Mukelabai, M. M., Muchinda, M., Kolle, O., and Scholes, R. J.: The Charcoal Trap: Miombo Forests and the Energy Needs of People, Carbon Balance Manag., 6, doi:10.1186/1750-0680-6-5, 2011.

Kuze, A., Suto, H., Nakajima, M., and Hamazaki, T.: Thermal and Near Infrared Sensor for Carbon Observation Fourier-Transform Spectrometer on The Greenhouse Gases Observing Satellite for Greenhouse Gases Monitoring, Appl. Optics, 48, 6716-6733, 2009.

Laporte, N. T., Stabach, J. A., Grosch, R., Lin, T. S., and Goetz, S. J.: Expansion of Industrial Logging in Central Africa, Science, 316, 1451, doi:10.1126/science.11410572007, 2007.

Lawrence, D. M., Oleson, K. W., Flanner, M. G., Thornton, P. E., Swenson, S. C., Lawrence, P. J., Zeng, X., Yang, Z- L., Levis, S., Sakaguchi, K., Bonan, G. B., and Slater, A. G.: Parameterization Improvements and Functional and Structural Advances in Version 4 of the Community Land Model, J. Adv. Model. Earth Syst., 3, 2011MS000045, doi:10.1029/2011MS000045, http://www.cesm.ucar.edu/models/cesm1.0/clm/lawrence.clm4. james.2011.pdf, 2011.

Lehsten, V., Tansey, K., Balzter, H., Thonicke, K., Spessa, A., Weber, U., Smith, B., and Arneth, A.: Estimating Carbon Emissions from African Wildfires, Biogeosciences, 6, 349-360, doi:10.5194/bg-6-349-2009, 2009.
Lehsten, V., Arneth, A., Thonicke, K., and Spessa, A.: Tree-Grass Coexistence in Savannahs: Testing Two Mechanisms, J. Veg. Sci., in review, 2014.

Levy, P. E., Cannell, M. G. R., and Friend, A. D.: Modelling the Impact of Future Changes in Climate, $\mathrm{CO}_{2}$ Concentration and Land Use on Natural Ecosystems and the Terrestrial Carbon Sink, Global Environ. Chang., 14, 21-30, 2004.

Lewis, S. L., Lopez-Gonzalez, G., Sonke, B., Affum-Baffoe, K., Baker, T. R., Ojo, L. O., Phillips, O. L., Reitsma, J. M., White, L., Comiskey, J. A., Djuikouo, M. N., Ewango, C. E. N., Feldpausch, T. R., Hamilton, A. C., Gloor, M., Hart, T., Hladik, A., Lloyd, J., Lovett, J. C., Makana, J. R., Malhi, Y., Mbago, F. M., Ndangalasi, H. J., Peacock, J., Peh, K. S. H., Sheil, D., Sunderland, T., Swaine, M. D., Taplin, J., Taylor, D., Thomas, S. C., Votere, R., and Woll, H.: Increasing Carbon Storage in Intact African Tropical Forests, Nature, 457, 1003-1006, 2009.

Liousse, C., Guillaume, B., Grégoire, J. M., Mallet, M., Galy, C., Pont, V., Akpo, A., Bedou, M., Castéra, P., Dungall, L., Gardrat, E., Granier, C., Konaré, A., Malavelle, F., Mariscal, A., Mieville, A., Rosset, R., Serça, D., Solmon, F., Tummon, F., Assamoi, E., Yoboué, V., and Van Velthoven, P.: Updated African Biomass Burning Emission Inventories in the Framework of the AMMAIDAF Program, with an Evaluation of Combustion Aerosols, Atmos. Chem. Phys., 10, 9631-9646, doi:10.5194/acp-10-9631201010.5194/acp-10-9631-2010, 2010.

Malhi, Y.: The Carbon Balance of Tropical Forest Regions, 19902005, Curr. Opin. Environ. Sust., 2, 237-244, 2010.

Malhi, Y.: The Productivity, Metabolism and Carbon Cycle of Tropical Forest Vegetation, J. Ecol., 100, 65-75, 2012.

Malhi, Y., Doughty, C., and Galbraith, D.: The Allocation of Ecosystem Net Primary Productivity in Tropical Forests, Philos. T. R. Soc. B, 366, 3225-3245, 2011.

Maniatis, D., Malhi, Y., Saint André, L., Mollicone, D., Barbier, N., Saatchi, S. S., Henry, M., Tellier, L., Schwartzenberg, M., and White, L.: Evaluating the Potential of Commercial Forest Inventory Data to Report on Forest Carbon Stock and Forest Carbon Stock Changes for REDD+ Under the UNFCCC, Int. J. Forest. Res., 2011, 134526, doi:10.1155/2011/134526, 2011.

Mapanda, F., Mupini, J., Wuta, M., Nyamangara, J., and Rees, R. M.: A Cross-Ecosystem Assessment of the Effects of Land Cover and Land Use on Soil Emission of Selected Greenhouse Gases and Related Soil Properties in Zimbabwe, Eur. J. Soil Sci., 61, 721-733, doi:10.1111/j.1365-2389.2010.01266.x, 2010.

Matthews, E. and Fung, I.: Methane Emissions from Natural Wetlands: Global Distribution, Area, and Environmental Characteristics of Sources, Global Biogeochem. Cy., 1, 61-86, 1987.

Mayorga, E., Seitzinger, S. P., Harrison, J. A., Dumon, E., Beusen, A. H. W., Bouwman, A. F., Fekete, B. M., Kroeze, C., and van Drecht, G.: Global Nutrient Export from Watersheds 2 (NEWS 2): Model Development and Implementation, Environ. Model. Softw., 25, 837-853, 2010.

Melack, J. M., Hess, L. L., Gastil, M., Forsberg, B. R., Hamilton, S. K., Lima, I. B. T., and Novo, E. M. L. M.: Regionalization of Methane Emissions in the Amazon Basin with Microwave Remote Sensing, Glob. Change Biol., 10, 530-544, 2004.

Melillo, J. M., Steudler, P. A., Feigl, B. J., Neill, C., Garcia, D., Piccolo, M. C., Cerri, C. C., and Tian, H.: Nitrous Oxide Emissions from Forests and Pastures of Various Ages in the Brazilian Amazon, J. Geophys. Res., 106, 34179-34188, 2001. 
Merbold, L., Ardö, J., Arneth, A., Scholes, R. J., Nouvellon, Y., de Grandcourt, A., Archibald, S., Bonnefond, J. M., Boulain, N., Brueggemann, N., Bruemmer, C., Cappelaere, B., Ceschia, E., El-Khidir, H. A. M., El-Tahir, B. A., Falk, U., Lloyd, J., Kergoat, L., Le Dantec, V., Mougin, E., Muchinda, M., Mukelabai, M. M., Ramier, D., Roupsard, O., Timouk, F., Veenendaal, E. M., and Kutsch, W. L.: Precipitation as Driver of Carbon Fluxes in 11 African Ecosystems, Biogeosciences, 6, 1027-1041, doi:10.5194/bg-6-1027-2009, 2009.

Meybeck, M., Durr, H. H., and Vorosmarty, C. J.: Global Coastal Segmentation and Its River Catchment Contributors: A New Look at Land-Ocean Linkage, Global Biogeochem. Cy., 20, GB1S90, doi:10.1029/2005GB002540, 2006.

Mitchard, E. T. A., Saatchi, S. S., Woodhouse, I. H., Feldpausch, T. R., Lewis, S. L., Sonké, B., Rowland, C., and Meir, P.: Measuring Biomass Changes Due to Woody Encroachment and Deforestation/Degradation in a Forest-Savanna Boundary Region of Central Africa Using Multi-Temporal L-Band Radar Backscatter, Remote Sens. Environ., 115, 2861-2873. doi:10.1016/j.rse.2010.02.022, 2011.

Nahlik, A. M. and Mitsch, W. J.: Methane Emissions from Tropical Freshwater Wetlands Located in Different Climatic Zones of Costa Rica, Glob. Change Biol., 17, 1321-1334, 2011.

Neill, C., Steudler, P. A., Garcia-Montiel, D. C., Melillo, J. M., Feigl, B. J., Piccolo, M. C., Cerri, C. C.: Rates and Controls of Nitous Oxide and Nitric Oxide Emissions Following Conversion of Forest to Pasture in Rondonia, Nutr. Cycl. Agroecosys., 71, 1-15, 2005.

Nicholson, S. E.: The Nature of Rainfall Variability over Africa on Time Scales of Decades to Millenia, Global Planet. Change, 26, 137-158, 2000.

Nicholson, S. E.: Climatic and Environmental Change in Africa During the Last Two Centuries, Clim. Res., 17, 123-144, 2001.

Nicholson, S. E. and Kim, J.: The relationship of the El Niño Southern Oscillation to African rainfall, Int. J. Climatol., 17, 117-135, 1997.

Papale, D. and Valentini, R.: A New Assessment of European Forests Carbon Exchanges By Eddy Fluxes and Artificial Neural Network Spatialization, Glob. Change Biol., 9, 525-535, 2003.

Patt, A. G. and Winkler, J.: Applying Climate Information in Africa: An Assessment of Current Knowledge, Written in support of NOAA, Boston University and the International Institute for Applied Systems Analysis (IIASA), 2007.

Peters, W., Krol, M. C., van der Werf, G. R., Houweling, S., Jones, C. D., Hughes, J., Schaefer, K., Masarie, K., Jacobson, A., Miller, J. B., Cho, C. H., Ramonet, M., Schmidt, M., Ciattaglia, L., Apadula, F., Heltai, D., Meinhardt, F., Di Sarra, A. G., Piacentino, S., Sferlazzo, D., Aalto, T., Hatakka, J., Ström, J., Haszpra, L., Meijer, H. A. J., Jordan, A., Rodó, X., Morgui, J. A., Vermeulen, A. T., Rozanski, K., Zimnoch, M., Manning, A., Leuenberger, M., Uglietti, C., Dolman, A. J., Ciais, P., Heimann, M., and Tans, P. P.: Seven Years of Recent European Net Terrestrial Carbon Dioxide Exchange Constrained by Atmospheric Observations, Glob. Change Biol., 16, 1317-1337, 2009.

Phillips, O. L., Aragao, L., Lewis, S. L., Fisher, J. B., Lloyd, J., Lopez-Gonzalez, G., Malhi, Y., Monteagudo, A., Peacock, J., Quesada, C. A., van der Heijden, G., Almeida, S., Amaral, I., Arroyo, L., Aymard, G., Baker, T. R., Banki, O., Blanc, L., Bonal, D., Brando, P., Chave, J., de Oliveira, A. C. A., Cardozo, N.
D., Czimczik, C. I., Feldpausch, T. R., Freitas, M. A., Gloor, E., Higuchi, N., Jimenez, E., Lloyd, G., Meir, P., Mendoza, C., Morel, A., Neill, D. A., Nepstad, D., Patino, S., Penuela, M. C., Prieto, A., Ramirez, F., Schwarz, M., Silva, J., Silveira, M., Thomas, A. S., ter Steege, H., Stropp, J., Vasquez, R., Zelazowski, P., Davila, E. A., Andelman, S., Andrade, A., Chao, K. J., Erwin, T., Di Fiore, A., Honorio, E., Keeling, H., Killeen, T. J., Laurance, W. F., Cruz, A. P., Pitman, N. C. A., Vargas, P. N., Ramirez-Angulo, H., Rudas, A., Salamao, R., Silva, N., Terborgh, J., and Torres-Lezama, A.: Drought Sensitivity of the Amazon Forest, Science, 323, 1344-1347, 2009.

Potter, C. E., Davidson, E., Nepsatd, D., and Carvalho, C. R.: Ecosystem modelling and dynamic effects of deforestation on trace gas fluxes in Amazon tropical forests, For. Ecol. Manage., 152, 97-117, 2001.

Potter, P., Ramankutty, N., Bennett, E. M., Donner, S. D.: Characterizing the Spatial Patterns of Global Fertilizer Application and Manure Production, Earth Interact., 14, 1-22, doi:10.1175/2009EI288.1, 2010

Poulter, B., Frank, D. C., Hodson, E. L., and Zimmermann, N. E.: Impacts of Land Cover and Climate Data Selection on Understanding Terrestrial Carbon Dynamics and the $\mathrm{CO}_{2}$ Airborne Fraction, Biogeosciences, 8, 2027-2036, doi:10.5194/bg8-2027-2011, 2011.

Prentice, I. C., Bondeau, A., Cramer, W., Harrison, S. P., Hickler, T., Lucht, W., Sitch, S., Smith, B., and Sykes, M. T.: Dynamic Global Vegetation Modelling: Quantifying Terrestrial Ecosystem Responses to Large-Scale Environmental Change, in: Terrestrial Ecosystems in a Changing World, edited by: Canadell, J. G., Pataki, D. E., and Pitelka, L. F., Springer, Heidelberg, Berlin, 175-192, 2007.

Prince, S. D., Wessels, K. J., Tucker, C. J., and Nicholson, S. E.: Desertification in the Sahel: A Reinterpretation of a Reinterpretation, Glob. Change Biol., 13, 1308-1313, 2007.

Purves, D. and Pacala, S.: Predictive Models of Forest Dynamics, Science, 320, 1452-1453, 2008.

Raymond, P. A., Oh, N.-H., Turner, R. E., and Broussard, W.: Anthropogenically Enhanced Fluxes of Water and Carbon from the Mississippi River, Nature, 451, 449-452, doi:10.1038/nature06505, 2008.

Raymond, P. A., Hartmann, J., Lauerwald, R., Sobek, S., McDonald, C., Hoover, M., Butman, D., Striegl, R., Mayorga, E., Humborg, C., Kortelainen, P., Dürr, H., Meybeck, M., Ciais, P., and Guth, P.: Global Carbon Dioxide Emissions from Inland Waters, Nature, 503, 355-359, doi:10.1038/nature12760, 2013.

Reason, C. J. C.: Sensitivity of the Southern African Circulation to Dipole Sea-Surface Temperature Patterns in the South Indian Ocean, Int. J. Climatol., 22, 377-393, 2002.

Reason, C. J. C. and Rouault, M.: ENSO-like Decadal Variability and South African Rainfall, Geophys. Res. Lett., 29, 1638-1642, 2002.

Richard, Y., Trzaska, S., Roucou, P., and Rouault, M.: Modification of the Southern African Rainfall Variability/ENSO Relationship Since the Late 1960s, Clim. Dynam., 16, 883-895, 2000.

Roberts, G. J. and Wooster, M. J.: Fire Detection And Fire Characterization Over Africa Using Meteosat SEVIRI, IEEE T. Geosci. Remote, 46, 1200-1218, 2008.

Saatchi, S. S., Harris, N. L., Brown, S., Lefsky, M., Mitchard, E. T. A., Salas, W., Zutta, B., Buermann, W., Lewis, S., Hagen, 
S., Petrova, S., White, L., Silman, M., and Morel, A.: Benchmark Map Of Forest Carbon Stocks In Tropical Regions Across Three Continents, P. Natl. Acad. Sci. USA, 108, 9899-9904, doi:10.1073/pnas.1019576108, 2011.

Sanderson, M. G.: Biomass of Termites and their Emissions of Methane and Carbon Dioxide: A Global Database, Global Biogeochem. Cy., 4, 543-557, 1997.

Saunders, M. J., Kansiime, F., and Jones, M. B.: Agricultural Encroachment: Implications for Carbon Sequestration in Tropical African Wetlands, Glob. Change Biol., 18, 1312-1321, 2012.

Scheiter, S. and Higgins, S. I.: Impacts of Climate Change on the Vegetation of Africa: An Adaptive Dynamic Vegetation Modelling Approach (aDGVM), Glob. Change Biol., 15, 2224-2246, 2009.

Scholes, R. J., Archibald, S. and von Maltitz, G.: Emissions From Fire in Sub-Saharan Africa: The Magnitude of Sources, their Variability and Uncertainty, Global Environ. Res., 15, 53-63, 2011.

Silva, J. M. N., Carreiras, J. M. B., Rosa, I., and Pereira, J. M. C.: Greenhouse Gas Emissions from Shifting Cultivation in the Tropics, including Uncertainty and Sensitivity Analysis, J. Geophys. Res., 116, D20304, doi:10.1029/2011JD016056, 2011.

Sitch, S., Smith, B., Prentice, I. C., Arneth, A., Bondeau, A., Cramer, W., Kaplan, J. O., Levis, S., Lucht, W., Sykes, M. Thonicke, K., and Venevsky, S.: Evaluation of Ecosystem Dynamics, Plant Geography and Terrestrial Carbon Cycling in the LPJ Dynamic Vegetation Model, Glob. Change Biol., 9, 161-185, 2003.

Sitch, S., Huntingford, C., Gedney, N., Levy, P. E., Lomas, M., Piao, S. L., Betts, R., Ciais, P., Cox, P., Friedlingstein, P., Jones, C. D., Prentice, I. C., and Woodward, F. I.: Evaluation of the Terrestrial Carbon Cycle, Future Plant Geography, and Climate-Carbon Cycle Feedbacks Using 5 Dynamic Global Vegetation Models (DGVMs), Glob. Change Biol., 14, 2015-2039, 2008.

Sitch, S., Friedlingstein, P., Gruber, N., Jones, S. D., MurrayTortarolo, G., Ahlström, A., Doney, S. C., Graven, H., Heinze, C., Huntingford, C., Levis, S., Levy, P. E., Lomas, M., Poulter, B., Viovy, N., Zaehle, S., Zeng, N., Arneth, A., Bonan, G., Bopp, L., Canadell, J. G., Chevallier, F., Ciais, P., Ellis, R., Gloor, M., Peylin, P., Piao, S., Le Quérá, C., Smith, B., Zhu, Z., and Myneni, R.: Trends and drivers of regional sources and sinks of carbon dioxide over the past two decades, Biogeosciences Discuss., 10, 20113-20177, doi:10.5194/bgd-10-20113-2013, 2013.

Sjöström, M., Zhao, M., Archibald, S., Arneth, A., Cappelaere, B., Falkf, U., de Grandcourt, A., Hanan, N., Kergoat, L., Kutsch, W., Merbold, L., Mougin, E., Nickless, A., Nouvellon, Y., Scholes, R. J., Veenendaal, E. M., and Ardö, J.: Evaluation of MODIS Gross Primary Productivity for Africa Using Eddy Covariance Data, Remote Sens. Environ., 131, 275-286, 2013.

Smith, B., Prentice, I. C., and Sykes, M. T.: Representation of Vegetation Dynamics in the Modelling of Terrestrial Ecosystems: Comparing Two Contrasting Approaches within European Climate Space, Global Ecol. Biogeogr., 10, 621-637, 2001.

Smith, L. K., Lewis Jr., W. M., Chanton, J. P., Cronin, G., and Hamilton, S. K.: Methane Emissions from the Orinoco River Floodplain, Venezuela, Biogeochemistry, 51, 113-140, 2000.

Tansey, K., Gregoire, J. M., Defourny, P., Leigh, R., Pekel, J. F. O., van Bogaert, E., and Bartholome, E.: A New, Global, MultiAnnual (2000-2007) Burnt Area Product at $1 \mathrm{Km}$ Resolution,
Geophys. Res. Lett., 35, L01401, doi:10.1029/2007GL031567, 2008.

Thornton, P. E., Lamarque, J. F., Rosenbloom, N. A., and Mahowald, N. M.: Influence of Carbon-Nitrogen Cycle Coupling on Land Model Response to $\mathrm{CO}_{2}$ Fertilization and Climate Variability, Global Biogeochem. Cy., 21, GB4018, doi:10.1029/2006GB002868, 2007.

Thornton, P. E., Doney, S. C., Lindsay, K., Moore, J. K., Mahowald, N., Randerson, J. T., Fung, I., Lamarque, J.-F., Feddema, J. J., and Lee, Y.-H.: Carbon-Nitrogen Interactions Regulate Climate-Carbon Cycle Feedbacks: Results from an AtmosphereOcean General Circulation Model, Biogeosciences, 6, 20992120, doi:10.5194/bg-6-2099-2009, 2009.

Tyson, P. D., Cooper, G. R. J., and McCarthy, T. S.: Millennial to Multi-Decadal Variability in the Climate of Southern Africa, Int J. Climatol., 22, 1105-1117, 2002.

United Nations Statistical Division (UNSTAT), United Nations Demographic Yearbook 2008, New York, United States, 2010.

UN Department of Economic and Social Affairs, United Nations Population Division, World Population Prospects: The 2010 Revision, http://esa.un.org/unpd/wpp/index.htm, 2011.

van der Werf, G. R., Randerson, J. T., Giglio, L., Collatz, G. J., Kasibhatla, P. S., and Arellano Jr., A. F.: Interannual Variability in Global Biomass Burning Emissions From 1997 to 2004, Atmos. Chem. Phys., 6, 3423-3441, doi:10.5194/acp-6-3423-2006, 2006.

van der Werf, G., Randerson, J., Giglio, L., Gobron, N., and Dolman, H.: Climate Controls on the Variability of Fires in the Tropics and Subtropics, Global Biogeochem. Cy., 22, GB3028, doi:10.1029/2007GB003122, 2008.

van der Werf, G. R., Randerson, J. T., Giglio, L., Collatz, G. J., Mu, M., Kasibhatla, P. S., Morton, D. C., DeFries, R. S., Jin, Y., and van Leeuwen, T. T.: Global Fire Emissions and the Contribution of Deforestation, Savanna, Forest, Agricultural, and Peat Fires (1997-2009), Atmos. Chem. Phys., 10, 11707-11735, doi:10.5194/acp-10-11707-2010, 2010.

Van Drecht, G., Bouwman, A. F., Knoop, J. M., Beusen, A. H. W., and Meinardi, C. R.: Global Modeling of the Fate of Nitrogen from Point and Nonpoint Sources in Soils, Groundwater and Surface Water, Global Biogeochem. Cy., 17, 1115, doi:10.1029/2003GB002060, 2003.

Van Wilgen, B. and Scholes, R. J.: The Vegetation and Fire Regimes of Southern Hemisphere Africa, in: Fire in Southern African Savannas: Ecological and Atmospheric Perspectives, edited by: Andreae, M., Goldammer, J., and Lindsay, K., Witwatersrand University Press, Johannesburg, 27-46, 1997.

Veenendaal, E. M., Kolle, O., and Lloyd, J.: Seasonal Variation in Energy Fluxes and Carbon Dioxide Exchange for a BroadLeaved Semi-Arid Savanna (Mopane Woodland) in Southern Africa, Glob. Change Biol., 10, 318-328, 2004.

Verchot, L. V., Davidson, E. A., Cattanio, J. H., Ackerman, I. L., Erickson H. E. and Keller, M.: Land Use Change and Biogeochemical Controls of Nitrogen Oxide Emissions from Soils in Eastern Amazonia, Global Biogeochem. Cy., 13, 41-46, 1999.

Verchot, L. V., Hutabarat, L., Hairiah, K., and van Noordwijk, M.: Nitrogen Availability and Soil $\mathrm{N}_{2} \mathrm{O}$ Emissions Following Conversion of Forests to Coffee in Southern Sumatra, Global Biogeochem. Cy. 20, GB4008, doi:10.1029/2005GB002469, 2006. 
Wang, S. Y. and Huang, D. J.: Assessment of Greenhouse Gas Emissions from Poultry Enteric Fermentation, Asian Austral. J. Anim., 18, 873-878, 2005.

Weber, U., Jung, M., Reichstein, M., Beer, C., Braakhekke, M. C., Lehsten, V., Ghent, D., Kaduk, J., Viovy, N., Ciais, P., Gobron, N., and Rödenbeck, C.: The Interannual Variability of Africa's Ecosystem Productivity: A Multi-Model Analysis, Biogeosciences, 6, 285-295, doi:10.5194/bg-6-285-200910.5194/bg-6285-2009, 2009.

Weitz, A. M., Veldkamp, E., Keller, M., Neff, J., and Crill, P. M.: Nitrous Oxide, Nitric Oxide and Methane Fluxes from Soils Following Clearing and Burning of Tropical Secondary Forest, J. Geophys. Res., 103, 28047-28058, 1998.

Williams, C. A.: Integration of Remote Sensing and Modeling to Understand Carbon Fluxes and Climate Interactions in Africa, in: Ecosystem Function in Savannas: Measurement and Modeling at Landscape to Global Scales, edited by: Hill, M. J. and Hanan, N., CRC Press, Boca Raton, FL, chap. 23, 327-346, 2010.

Williams, C. A. and Hanan, N. P.: ENSO and IOD Teleconnections for African Ecosystems: Evidence of Destructive Interference between Climate Oscillations, Biogeosciences, 8, 27-40, doi:10.5194/bg-8-27-201110.5194/bg-8-27-2011, 2011.

Williams, C. A., Hanan, N. P., Neff, J. C., Scholes, R. J., Berry, J. A., Denning, A. S., and Baker, D. F.: Africa and the Global Carbon Cycle, Carbon Balance Manag., 2, 1-13, 2007.

Williams, C. A., Hanan, N. P., Baker, I., Collatz, G. J., Berry, J., and Denning, A. S.: Interannual Variability of Photosynthesis across Africa and its Attribution, J. Geophys. Res., 113, G04015, doi:10.1029/2008JG000718, 2008.

Woodward, F. I. and Lomas, M. R.: Vegetation-Dynamics - Simulating Responses to Climate Change, Biol. Rev., 79, 643-670, 2004.
Woodward, F. I., Smith, T. M., and Emanuel, W. R.: A Global Land Primary Productivity and Phytogeography Model, Global Biogeochem. Cy., 9, 471-490, 1995.

Wooster, M. J., Roberts, G., Perry, G. L. W., and Kaufman, Y. J.: Retrieval of Biomass Combustion Rates and Totals from Fire Radiative Power Observations: FRP Derivation and Calibration Relationships between Biomass Consumption and Fire Radiative Energy Release, J. Geophys. Res., 110, D24311, doi:10.1029/2005JD006318, 2005.

Yu, K. W., Faulkner, S. P., and Baldwin, M. J.: Effect of Hydrological Conditions on Nitrous Oxide, Methane, and Carbon Dioxide Dynamics in a Bottomland Hardwood Forest and Its Implication for Soil Carbon Sequestration, Glob. Change Biol., 14, 1-15, 2008.

Zaehle, S. and Friend, A. D.: Carbon and Nitrogen Cycle Dynamics in the O-CN Land Surface Model: 1. Model Description, SiteScale Evaluation and Sensitivity to Parameter Estimates, Global Biogeochem. Cy., 24, GB1005, doi:10.1029/2009GB003521, 2010.

Zeng, N.: Glacial-Interglacial Atmospheric $\mathrm{CO}_{2}$ Change - the Glacial Burial Hypothesis, Adv. Atmos. Sci., 20, 677-673, 2003.

Zeng, N., Mariotti, A., and Wetzel, P.: Terrestrial Mechanisms of Interannual $\mathrm{CO}_{2}$ Variability, Global Biogeochem. Cy., 19, GB1016, doi:10.1029/2004GB002273, 2005.

Ziehn, T., Scholze, M., and Knorr, W.: Regionalisation of the Key Carbon Storage Parameter within the Carbon Cycle Data Assimilation System (CCDAS), EGU General Assembly, Vienna, Austria, 2010.

Zomer, R. J., Trabucco, A., Coe, R., and Place, F.: Trees on Farm: Analysis of Global Extent and Geographical Patterns of Agroforestry, ICRAF Working Paper no. 89, World Agroforestry Centre, Nairobi, Kenya, 2009. 